\title{
Phonological constituents and their movement in Latin
}

\begin{abstract}
We document a fronting process in Latin that is difficult to model as syntactic movement but fairly easy to model as phonological movement. The fronted material often cannot be analyzed as a syntactic constituent, and the fronting, motivated by discourse prominence factors, is insensitive to island constraints and LF properties which are otherwise typical of syntactic movement. The fronted material can, however, be analyzed as prosodic words and phonological phrases, and movement is blocked when it brings together homophonous function words. Movement with similar properties has been observed elsewhere in Classical Greek, Russian, Irish, and Japanese; we suggest that the Latin movement is of the same type and takes place in the phonological component of the grammar, following the mapping from syntactic to prosodic structure. These observations suggest that syntax and phonology operate in different spheres, such that syntactic alternations can have no phonological conditions, and phonological alternations can have no syntactic conditions. As such, phenomena that require reference across the syntax-phonology divide cannot exist.
\end{abstract}

\section{Introduction ${ }^{1}$}

Natural languages group words into syntactic and prosodic constituents, based on requirements that often conflict. A Latin string like that in (1) has the syntactic structure in (2) based on lexical $(\mathrm{N}, \mathrm{V}, \mathrm{A})$ and functional $(\mathrm{P})$ heads and their projections:

\footnotetext{
${ }^{1}$ For helpful comments and questions we'd like to thank audiences at Auckland University, Stockholm University, California State University Fresno, the University of California Santa Cruz, the UCLA Indo-European Conference, the Annual Meeting on Phonology at MIT, Parallel Domains: a Workshop in Honor of Jean-Roger Vergnaud at USC, and The Prosodic hierarchy in a typological perspective at Stockholm University. Special thanks to A.M. Devine, Lawrence Stephens, and Ben Fortson for help with the Latin, to three anonymous reviewers at Phonology, and to Arto Anttila for helping us clarify the presentation of our ideas. Any errors of data and/or analysis are our own.
} 
(1) afferre ad communem fructum contribute $_{\mathrm{INF}}$ to common $_{\mathrm{ACC}}$ fruit $_{\mathrm{ACC}}$

'to contribute to the common good'

(2)

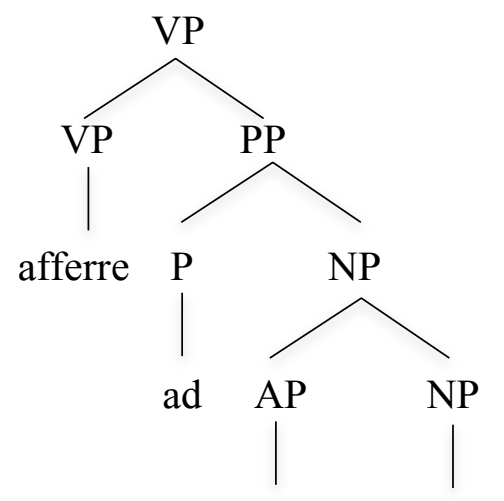

communem fructum

The same string has a prosodic structure based on the right-alignment of prosodic edges to syntactic edges (3):

(3)

)$_{\varphi} \quad$ Phonological Phrase

$(\text { afferre })_{\omega}(\text { ad communem })_{\omega}(\text { fructum })_{\omega} \quad$ Prosodic Word

Syntactic constituency differs from prosodic constituency in a number of ways. In the case at hand, the string ad communem is not a syntactic constituent, straddling a preposition and the first half of its complement, but it is a phonological constituent $\omega$ consisting of a functional head plus a following lexical head (Selkirk 1984, 1986, 1996).

This difference between syntactic and prosodic structure becomes crucial when we consider how focused and topicalized material is fronted in Latin, a process known traditionally as hyperbaton (see Adams 1971, Devine \& Stephens 2000, Bolkestein 2001, Devine \& Stephens 2006, Agbayani \& Golston 2010a for hyperbaton in Classical Greek; Powell 2010 for hyperbaton in Latin). The general view is that hyperbaton involves fronting and that the fronting involves focus, topicalization, or some other kind of discourse prominence. Consider the following example of hyperbaton from Cicero, derived from (1) through fronting of ad communen:
(4) ad communem
afferre fructum]
to common $_{\mathrm{ACC}}$ to.contribute fruit $_{\mathrm{ACC}}$
'to contribute to the common good' (Cicero, Pro Archia 12) 
The string ad communem has moved to the left of the verb, splitting the PP ad communem fructum (italicised to highlight the discontinuity). Notice, however, that while ad communem is a prosodic constituent (3), it is not a syntactic constituent (2), ${ }^{2}$ suggesting that the movement is phonological - that is, movement of a prosodic constituent in the phonological componentrather than syntactic. We present here a range of evidence that hyperbaton in Latin is phonological movement. The data discussed here are similar to data found in Classical Greek (Agbayani \& Golston 2010a), Russian (Agbayani, Golston \& Henderer 2011), and Ukrainian (Teliga 2011). Related facts can be found in Japanese (Agbayani, Golston \& Ishii 2015), in which prosodic scrambling of a recursive phonological phrase occurs in the phonological component in situations where XP scrambling in the syntax is not available; and in Irish (Bennett, Elfner and McCloskey to appear), in which pronominals shift rightward to satisfy the STRONGSTART constraint (Selkirk 2011).

The bulk of this article lays out the evidence for prosodic words $(\omega)$ and phonological phrases $(\varphi)$ in Latin $(\S 2)$ and the characteristics of hyperbaton there $(\S 3)$. We then show that extant syntactic analyses of hyperbaton are inadequate and present an analysis based on phonological movement $(\S 4)$.

\section{Latin prosody}

More than a century's worth of research has established that function words in Latin are prosodically dependent on nearby lexical words; prosodically dependent function words are often called 'appositives' in the literature on Latin (not to be confused with NP appositives in contemporary syntactic analysis). The degree of dependency seems to correlate with the morphological and phonological complexity of the function word: simplex function words (conjunctions, complementizers, and prepositions) are heavily dependent on nearby content words - though monosyllabic prepositions are more dependent than polysyllabic prepositions-while morphologically complex function words (demonstratives, adverbials, pronominals) are also dependent but less so. Evidence for all of this comes from several areas, including direct testimony from ancient authors (2.1), word-break conventions in orthography (2.2), and phrasing in poetic meter (2.3). The combined evidence points to function words forming recursive prosodic words with nearby content words (Selkirk 1996), either as words themselves (demonstratives, adverbials, pronominals) or merely as the phonological feet that Latin employs, moraic trochees (2.4).

\footnotetext{
${ }^{2}$ It cannot be the case that ad communem and fructum form separate syntactic DPs/NPs, since the adjective communem participates in (accusative) case concord with the modified noun fructum, suggesting a syntactic relation of modification originating within the same DP/NP.
} 


\title{
2.1 Ancient testimony
}

Direct evidence for the prosodic dependence of function words on adjacent content words comes from authors like Quintilian $\left(1^{\text {st }} \mathrm{c}\right.$.), who says that a preposition and a noun are pronounced as a single word when joined together: 'For when I say circum litora [around the beach], I speak it as one thing without separation, and so it is made one, as if in one utterance [nam cum dico "circum litora", tamquam unum enuntio dissimulata distinctione, itaque tamquam in una voce una est acuta... (1.5.27)].

The grammarian Audax $\left(4^{\text {th }} \mathrm{c}\right.$.) says plainly that 'all prepositions in fact are without an accent' [GL VII,320-361,12]. He goes on to say that

not all parts of speech are equal. 'For noun and verb and participle dominate among all the parts of speech; following these the others seem like appendages. For a pronoun is connected with a noun, and an adverb serves a verb. A conjunction too and a preposition are dependents of the major parts of speech. So these parts of speech, which are appendages, are so joined together with the major ones that they coalesce into one utterance and lose their own accent entirely, not all to this extent, but most.' (Audax, K. VII, 360.)]

Finally, authors like Cicero $\left(1^{\text {st }} \mathrm{c} B C E\right)$, Quintilian, and Velius Longus $\left(2^{\text {nd }} \mathrm{c}\right.$. $)$ report cases of external sandhi involving function words, like the place assimilation in cun nobis for cum nobis 'with us' or etian nunc for etiam nunc 'so now'. Orthographic evidence backs this up as well, as we see in the next section.

\subsection{Orthography}

Additional evidence for the prosodic subordination of function words comes from the distribution of the interpunct (·) in Latin monuments, graffiti, and manuscripts. Roman orthography was generally written in scriptio continua, which lacked spaces between words, but some writing and nearly all inscriptions used an interpunct (·) to show word breaks, as in this fragments from a letter (Adams 1995, 96):

\author{
(5) dehac.re \\ about this:thing \\ 'about this thing' (fragment 211)
}

Fragment 211 shows the case we're especially interested in, where the phonological/ orthographic constituency (de hac)(re) (about this)(thing) differs from the syntactic 
constituency [de [hac re]]) [about [this thing]]. There is often no interpunct between various kinds of function word and an adjacent lexical word: this is most common between a preposition and a following word (Wingo 1972, 16; dehac, adVocosium), a conjunction and a following word (Corsen 1859, 868; etalias), or a complementizer and a following word (utcarrula). But it also takes place between a verb and a following pronoun (Adams 1996; carrulavobis), showing that function words are dependent on content words generally, some on those that precede (pronouns) and some on those that follow (prepositions, conjunctions, complementizers).

Authors from Blair (1874) and Greenough (1894) to Fortson (2008) note that place and voicing assimilation occur in external sandhi in texts and on monuments (6). Almost all cases apply to function words, as the following shows, from the Corpus Inscriptionum Latinarum (CIL):

\section{(6) SET QUI \\ sed qui ‘but who’ (CIL X 2496.5)}

As set qui shows, the assimilation takes place within a prosodic word whose members may not be sisters syntactically, showing that the process is prosodically rather than syntactically bounded, as is the case with external sandhi generally (Nespor \& Vogel 1986; Selkrik 1986; Hayes 1989). Similar phenomena are found in manuscripts (Ribbeck 1866, pp. 433-4):

\section{(7) im pace in pace 'in peace'}

Similarly, the manuscripts of Plautus often show the copula written as part of the preceding participle or adjective: locutast for locuta est 'is spoken', copiast for copia est 'are many', and so on, suggesting that the copula formed a prosodic word with its complement (see Fortson 2008:134-175).

\subsection{Metrical evidence}

Additional evidence that function words formed prosodic words with adjacent content words comes from poetic meter, especially the lining up of the edges of function and content words with verse feet in the classical meters of Latin.

Most Latin poetry is in meters borrowed from Greek, in which the edges of prosodic words pattern pretty much the same whether they consist of a single lexical word or of one or more function words next to a lexical word. Certain positions in the line ('caesurae') require 
word-breaks, and certain positions ('bridges') abjure them; but what counts as a word-break for either is what counts as a word break in the orthography or in phonological movement. Over a century's worth of research confirms that function words are prosodically subordinated in Latin meter just as they are in writing:

According to an oft-repeated rule of the grammarians the monosyllables are usually without the accent... This rule does not apply of course to monosyllabic nouns and verbs, as many other testimonies of the grammarians show...but only to those words which, owing to their meaning, are naturally unaccented in many languages, viz., the monosyllabic prepositions, conjunctions, pronouns, and adverbs. (Radford 1903: 63)

Metrical work on where word-stress falls in a line of poetry shows that many function words fuse so closely with the following word that they are positioned within the line as if they were a single word. Thus Frank (1904) finds that strings like sed id 'but it', sed amor 'but love', sed homines 'but men' pattern like two-, three- and four-syllable lexical words do. With trisyllables in particular, Frank shows that function words so closely adhere to what follows that they can take the only accent of the group: séd agit rather than sed ágit 'but I lead' and séd erus rather than sed érus 'but the head of the family', where the recessive accent expected on the content word shows up on the preceding function word. Frank points out that the same types of combination are often written together in manuscripts: etea for et ea 'and those', utipse for ut ipse 'so that he'. His data suggest that 'the monosyllabic particles...like all other independent words, have originally an accent, as in fact the grammarians expressly declare; if they very frequently lose this accent, this happens simply because they are subordinated in sense to the other words of the sentence and, at the same time, in the majority of cases, cannot preserve their accent through the operation of the three-syllable law' (1904: $160)$.

Mercado has recently argued that early Latin Saturnian meter distinguishes primary, secondary, and zero stress and that 'function-word accent is scanned the same way as secondary stress' (2012:115). Primary stress in polysyllabic content words has to occur in metrically strong positions in the line, but this is not the case for the single stress in polysyllabic function words: 'secondary stress-bearing syllables and primary-stressed syllables in function words admit of variable scansion, depending on what metrical positions they fill and on the phonological prominences of the syllables that occupy the metrical positions immediately following' (p. 110). Monosyllabic content words and monoysllabic function words pattern the same in Saturnian (p. 116ff.), though it does not follow from that that they were prosodically identical. What we can be sure of is that function words didn't carry the 
same kind of primary stress that content words carried, thus that they were somehow prosodically subordinated.

\subsection{Prosodic constituency}

In current terminology, it appears that function words form recursive prosodic words with nearby content words (Booij 1996, Selkirk 1996):

(8) (

) Phonological Phrase

(afferre) (ad (communem)) (fructum) Prosodic Word

So while afferre (verb) and fructum (noun) form their own prosodic words above, ad (preposition) must be adjoined to the prosodic word formed by communem (adjective). We will discuss the exact prosodic size of function words in what follows: in principle they could be syllables, feet, or prosodic words. All words in Latin are minimally bimoraic, whether function words or content words (Allen 1973:51; see also Golston 1991, Mester 1994). We can therefore surmise that function words are either bimoraic feet or prosodic words. Since syllables can be light or heavy in Latin while feet are bimoraic, the simplest assumption is that functional heads (other than clitic heads like =que 'and' and =ve 'or') are minimally bimoraic because they are minimally a foot. We will assume that conjunctions, complementizers, and prepositions (which never move) are just feet, while pronouns, whwords, auxiliaries, closed-class adverbs, and the like (which do move) are prosodic words. ${ }^{3}$

\section{Hyperbaton in Latin}

Hyperbaton takes place against a backdrop of fairly free constituent order, such that S, V, and $\mathrm{O}$ can occur in any order, even in mundane prose texts (see inter alia, Devine \& Stephens 2006; Spevak 2010; Danckaert 2012):

\footnotetext{
${ }^{3}$ An anonymous reviewer notes that prepositions actually can get moved leftward out of a PP with the preposition per in oaths, but notes that this is probably 'an archaic holdover of an earlier time when prepositions were free-floating adverbials that could be fronted like any other constituent'. The reviewer notes that Ps can be fronted in poetry as well and points out that both facts potentially support our claim that hyperbaton acts on almost any syntactic type. We leave this to future research, as archaisms and poetry are not our concern here.
} 
(9) SVO

avus eius in Africa manu propria occidit elephantem

grandfather $_{\mathrm{NOM}}$ his in Africa ${ }_{\mathrm{ABL}}$ hand $_{\mathrm{ABL}}$ own $_{\mathrm{ABL}}$ killed $_{3}$ elephant $_{\mathrm{ACC}}$

'his grandfather killed an elephant in Africa with his own hand' (Honoratus, CV 286)

(10) SOV

insecuti magnum ex is numerum occiderunt

pursuers $_{\text {NoM }}$ great $_{\mathrm{ACC}}$ of them $\mathrm{ABL}_{\text {n }}$ number $_{\mathrm{ACC}}$ killed $_{3 \mathrm{P}}$

'the pursuers killed a great number of them' (Caesar, Bello Gallico 1.53.1)

(11) OSV

Germanum Cimber occidit

Germanus $_{\text {ACC }}$ Cimber $_{\text {NoM }}$ killed $_{3}$

'Cimber killed Germanus' (Cicero, Philippics 11.6.14)

(12) VOS

occidit Saturninum Rabirius

killed $_{3}$ Saturninus $_{\text {AсC }}$ Rabirius $_{\text {мом }}$

'Rabirius killed Saturninus' (Cicero, pro C. Rabiro postumo 11.31)

(13) VSO

vidit...pater tuus Appium Claudium

saw $_{3}$ father $_{\text {Nom }}$ your $_{\text {Nom }}$ Appium $_{\text {AсC }}$ Claudius $_{\text {ACC }}$

'your father saw Appius Claudius' (Cicero, pro Plancio 21.51)

(14) OVS

patrem occidit Sextus Roscius

father $_{\text {Aсc }} \quad$ killed $_{3}$ Sextus $_{\text {ком }}$ Roscius $_{\text {мом }}$

'Sextus Roscius killed his father' (Cicero, pro Sextus Roscio 14.39)

Devine and Stephens (2006, henceforth D\&S) posit that the canonical surface order of major constituents in Latin is SOV, specifically:

(15) ${ }_{\mathrm{IP}} \mathrm{S}$ [vp IO/Obl [vp Adjunct [ ${ }_{\mathrm{vP}} \mathrm{Goal} /$ Source [vp DO V]]]] 
They propose that this order is derived syntactically from an underlying order in which the VP is head-initial. Danckaert argues for an underlying VO structure as well (2012: 312ff). We lack data currently that shows whether the word order in (15) is derived syntactically or phonologically, and leave this issue to future research. Our focus henceforth will be on hyperbaton.

Hyperbaton is the traditional term for fronting that results in a discontinuous constituent, and it is clear when a constituent is split even when it is not clear what the head/complement order was before the split occurred. Consider the OSV case above in (11); we do not know if it comes from SVO or SOV underlyingly, but this need not keep us from recognizing that the object has been fronted from some position within VP and that the VP is now discontinuous, split by the subject.

The core cases of hyperbaton involve movement of units smaller than a full XP, where a basic order is sometimes easier to come by. Prepositional phrases, for instance, are usually head-initial on the surface (16) but allow material from the object to be fronted just past the preposition (17) as long as the entire object is not fronted (18):

(16) ex una parte

from one parL $_{\mathrm{ABL}}$

'from one part'(Seneca the Elder, Controversiae 6.3)

(17) una ex [__ parte]

one $_{\mathrm{ABL}}$ from part $_{\mathrm{ABL}}$

'from one part' (Caesar, Bello Gallico 1.2)

(18)*una parte ex [__

one $_{\mathrm{ABL}}$ part $_{\mathrm{ABL}}$ from

'from one part' [construct]

(17) is the traditional hyperbaton case (since una...parte is a discontinuous constituent), and we can assume that it is derived from (16) rather than from (18) - that is, via leftward movement/fronting rather than via rightward movement or base generation-because (16) is extremely common while (18) is completely unattested. Quintilian provides the following remarks on the matter:

When, however, the transposition is confined to two words only, it is called anastrophe, that is, a reversal of order. This occurs in everyday speech in mecum and secure, while in orators and historians we meet with it in the phrase quibus de rebus. 
It is the transposition of a word to some distance from its original place, in order to secure an ornamental effect, that is strictly called hyperbaton: the following passage will provide an example: animadverti, indices, omnem accusatoris orationem in duas divisam esse partes. ("I noted, gentlemen, that the speech of the accuser was divided into two parts.") In this case the strictly correct order would be in duas partes divisam esse, but this would have been harsh and ugly. (Quintilian, Institutio Oratoria 8 6.65, tr. Butler)

Other data that argue for fronting include long distance cases like the following (cited in Spevak 2010):

(19) si qua ego [in__re] fratri tuo rei publicae causa restiterim if any $_{\mathrm{ABL}} \mathrm{I}_{\mathrm{NOM}}$ in matter $_{\mathrm{ABL}}$ brother $_{\mathrm{DAT}}$ your $_{\mathrm{DAT}}$ thing $_{\mathrm{GEN}}$ public $_{\mathrm{GEN}}$ because opposed $_{1 . \mathrm{PF} . \mathrm{SB} \mathrm{J}}$ 'if I have opposed your brother in any matter of the public good...' (Cicero, Fam. 5.2.6)

qua 'any' is fronted out of in qua re 'in any matter' over the subject ego 'I'. Fronting qua leftwards is much simpler than scrambling in re rightwards, since the subject has scope over the PP and presumably starts out in front of it. In addition, consider the following (from Pinkster 2005), where the adjective has moved across equidem 'though', which clearly has scope over the whole PP, making an analysis with rightward movement hard to imagine:

$\begin{array}{lll}\text { magno equidem [cum } & \text { dolore } \\ \text { great }_{\mathrm{ABL}} & \text { though with } & \text { sorrow }_{\mathrm{ABL}}\end{array}$

'though with great sorrow' (Cicero, Att. 10.4.5)

The following type of example makes leftward movement inescapable:

$$
\begin{array}{lllll}
\text { oleum } & \text { si }[\text { in } & \text { metretam novam } & & \text { inditurus] eris } \\
\text { oil }_{\mathrm{ACC}} & \text { if into } \operatorname{jar}_{\mathrm{ACC}} \quad \text { new }_{\mathrm{ACC}} & \text { be.put.in } \mathrm{want}_{2}
\end{array}
$$

'if you want oil to be put into a new jar' (Cato 100)

Everything is in place here except for oleum, which appears far to the left of its VP. If oleum did not move, it's very hard to see how everything ended up where it did. Consider the following as well: 
(22) meo tu epistulam dedisti $\left[\begin{array}{l}\text { servo }] \\ \text { my }_{\text {DAT }} \text { you }_{\text {NOM }} \text { letter }_{\text {ACC }} \text { gave }_{\text {3PERF }}\end{array}\right.$
'You gave the letter to my servant?' (Plautus, Pseudolus 1203; Panhuis 1982)

Here the possessive adjective meo is fronted past the verb, object, and subject; fronting is the traditional view, the one taken in D\&S 2006, and the one we adopt here.

It is more difficult to say exactly what 'discourse prominence' is. It often involves focus, so D\&S treat hyperbaton as syntactic movement to one of many [spec, Focus] positions. But they stress that the moved piece isn't always exactly focused, and that what remains in situ is sometimes focused as well:

[T] here are enough instances that do not conform to the usual pragmatic structure to show that premodifier hyperbaton is a properly syntactic process not tied to a single pragmatics.... So the correct generalization is that premodifier hyperbaton, like hyperbaton in general, is just partial movement. Part of the phrase moves (for whatever reason movement is licensed in any particular instance) and part is stranded. (D\&S 2006: 548)

The clearest cases of hyperbaton are those that create discontinuous constituents locally, like the following, where illis 'those' is made discontinuous from its NP by intervening autem 'but':

(23) in illis autem _ meis actionibus sententiis =que omnibus
in those ${ }_{\mathrm{ABL}}$ but $\mathrm{my}_{\mathrm{ABL}}$ actions $_{\mathrm{ABL}}$ motions $_{\mathrm{ABL}}$ and $\mathrm{all}_{\mathrm{ABL}}$
'but in those actions of mine and all those motions' (Cicero, ad Familiares 1.9.10)

The PP headed by in is also thereby made discontinuous, of course, but we tend to notice the lower discontinuities more. Fronting an adjective past a preposition makes a discontinous NP (magna cum __ laude 'with great praise'), fronting an object over a subject makes a discontinuous VP (13), fronting a subject over a complementizer makes a discontinuous TP (23), and so on. A moment's reflection shows that all non-local movement creates discontinuous constituents; so we make no principled distinction between partial and full hyperbaton. The main issue this paper seeks to tackle is whether such fronting is syntactic or prosodic, which we address in detail in section (§4).

It is not always clear what the basic order of lexical heads and their complements is; lexical heads ( $\mathrm{N}, \mathrm{V}, \mathrm{A})$ can occur before, within, and after their complements and are responsible for most of the apparent free word order and so-called non-configurationality of 
Latin. Nouns, for instance, usually occur before their complements (complement italicised),

(24) spes potiundi oppidi

hope $_{\text {NOM }}$ taking $_{\text {GEN }}$ town $_{\text {GEN }}$

'hope of taking the town' (Caesar, Bello Gallico 2.7)

but part of the complement may be fronted very locally just past the head as well, the case traditionally called 'hyperbaton':

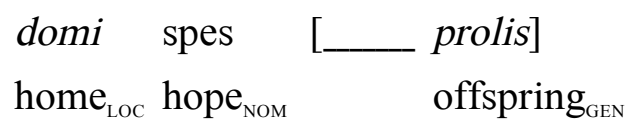

'hope of offspring at home' (Livy, 1.9)

There is no traditional term for the third case, when the full complement is fronted past the head, so we call this full hyperbaton, distinguishing it from the partial hyperbaton we just saw:

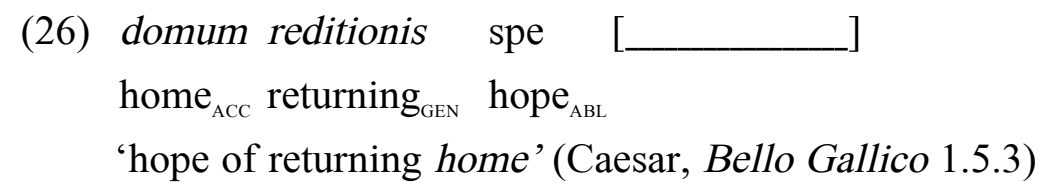

We see no deep distinction between full and partial hyperbaton, since it is only a matter of whether part or all of the complement has been fronted past the head. We will therefore discuss both in tandem in what follows; the reader should remember, however, that the traditional notion of hyperbaton is narrower and usually only includes the partial type. We treat both types as phonological movement, though the argument against syntactic movement is clearer for partial hyperbaton, where obvious discontinuous constituents result, than for full. Even with full hyperbaton, though, we see insensitivity to various syntactic conditions, suggesting that it is on a par with the partial cases as an instance of phonological movement of a prosodic constituent.

The rest of this section explores the core properties of hyperbaton, both partial and full. Many of these make a syntactic analysis difficult (3.1-3.12); others specifically suggest a phonological analysis (3.13-16).

\subsection{Category neutrality}

Hyperbaton moves material of almost any syntactic type and thus appears to be category neutral. The only syntactic categories that do not undergo hyperbaton in Latin are 
complementizers, conjunctions, and prepositions, which do not form a natural class syntactically. They do, however, form a phonological class of sorts, in that they are not prosodically autonomous, but readily cliticise onto other categories (see discussion in section 2 above). We therefore suggest that they can't move because they are just feet and not phonological words, though for conjunctions and complementizers it is hard to see what would motivate moving them in the first place. We begin with what does move in Latin and then look at what does not.

Below we see discontinuous constituents (italicised) that result from moving a demonstrative (a), noun (b), relative pronoun (c), and verb (d):

a. hanc cum habeat [___ praecipuam laudem]

this $_{\mathrm{ACC}}$ since has $_{3 \mathrm{SUBJ}} \quad$ particular $_{\mathrm{ACC}}$ merit $_{\mathrm{ACC}}$

'since he has this particular merit' (Cicero, Brutus 261)

b. potestatem Pompeio [_ civitatem donandi $]$ dederat

power $_{\mathrm{ACC}}$ Pompey $_{\mathrm{DAT}} \quad$ citizenship $_{\mathrm{ACC}}$ giving $_{\mathrm{GEN}}$ given $_{3 \mathrm{PF}}$

'he had given to Pompey the power of giving citizenship' (Cicero, Pro Balbo 32)

c. quas inter [__ et castra $]$

which $_{\text {ACC.PL }}$ between and camp ACC.PL $_{\text {. }}$

'between which and the camp' (Caesar, Bello Gallico 6.36)

d. conclamant Haedui [__ et Litaviccum obsecrant]

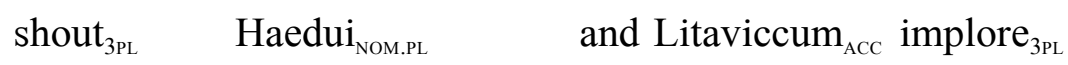

'the Haedui shouted and implored Litaviccus' (Caesar, Bello Gallico 7.38)

The list is representative, not exhaustive. This diversity of targets is important because syntactic movement usually targets very specific categories (wh-words, NPs, verbs, auxiliaries, etc.), rather than categories in general.

The same variety is found for full hyperbaton, where we see movement of an adverbial adjunct (a), NP subject (b), VP (c), etc.:

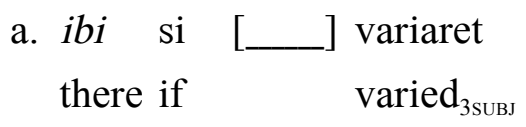

'If it varied there' (Livy 1.43.11) 
b. olea si [___ $]$ fructum non feret

olive $_{\text {Nom }}$ if fruit $_{\text {ACC }}$ not bear $_{3}$

'If an olive (tree) doesn't bear fruit...' (Cato 93)

c. nam convenit harundinetum [__ $]$ cum corruda

for goes.well reed.thicket $_{\mathrm{NOM}} \quad$ with wild.asparagus ${ }_{\mathrm{ABL}}$

'for a reed-thicket works well with wild-asparagus' (Cato 6)

Note that (a-b) front an adverb and NP past a complementizer, while (c) fronts a verb just past the subject: the targets are as heterogeneous as the places they move to.

There are three items that hyperbaton does not target in Latin: complementizers ( $s i$ 'if', nam 'for', etc.), conjunctions (et 'and', sed 'but', etc.), and prepositions (cum 'with', ex 'out of', etc.). In section 3.8, we ascribe this to the prosodic size of such elements, that they are merely feet, and not prosodic words.

\section{2 'Bar-level' neutrality}

Hyperbaton equally affects things that are $\mathrm{X}^{0}$ and $\mathrm{XP}$ in the syntax and thus seems to be neutral with respect to head or phrasal status, a surprising result if the movement is syntactic. Cases of moved heads $(27)$ and phrases $(27,28)$ that consist of a single lexical item have already been presented. Additional cases include wh-heads (29) and subject NPs (30):

(29) quis umquam [__ Graecus] comoediam scripsit... which $_{\text {Nom }}$ ever Greek Nom $_{\text {Nomedy }}$ Acc wrote $_{3}$

'Which Greek ever wrote a comedy...?' (Cicero, pro Flacco 27.65)

(30) festus dies cum [___ ] erit

festive $_{\text {мом }}$ day $_{\text {оом }}$ when $\quad$ is $_{3 \mathrm{~s}}$

'when (it) is a holiday' (Cato 143.2)

The fact that hyperbaton moves both heads and phrases to what appear to be the same positions is problematic for syntactic accounts because heads and phrases typically have different landing sites. 


\subsection{Non-constituent movement}

A startling property of hyperbaton involves the movement of strings that are not syntactic constituents:

(31) in eodem occiderint [__ castello]

in same $_{\text {ABL }} \operatorname{died}_{3 \text { P.P. SUBJ }} \quad$ castle $_{\text {ABL }}$

'died in the same castle' (Caesar, Bello Gallico 37)

The problem for any syntactic analysis is that the moved string in eodem does not form a syntactic constituent and thus should not move. This is clear from the premovement syntactic constituency for (31):

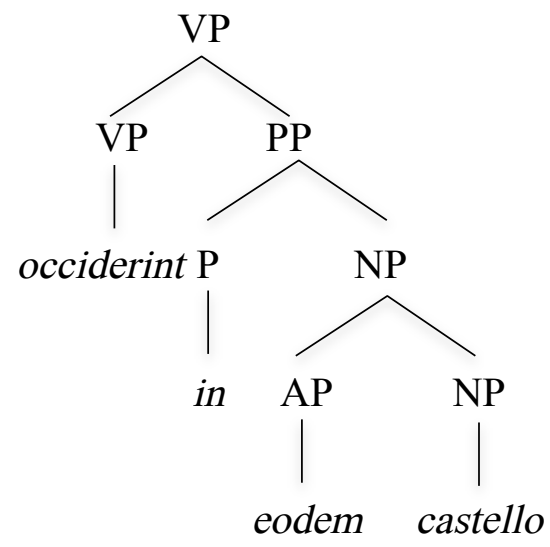

Similar cases occur with VP and PP:

conatus est Caesar [reficere pontes ___

tried $_{\text {NoM }}$ has $_{3}$ Caesar $_{\mathrm{NOM}}$ repair $_{\mathrm{INF}}$ bridges $_{\mathrm{ACC}}$

'Caesar has tried to repair the bridges' (Caesar, Bello Civili 1.50; D\&S 147)

(34) hanc unam $[\mathrm{ob}$
this $_{\mathrm{ACC}}$ one $_{\mathrm{ACC}}$ from

'from this one cause' (Cicero, ad Atticum 7.9.2)

Cases like this can be multiplied ad libitum. ${ }^{4}$

\footnotetext{
${ }^{4}$ For similar cases in south Slavic, Bošković (2005) proposes that adjectives move to a position c-commanding $\mathrm{P}$, which then cliticizes onto the adjective prior to further leftward
} 


\subsection{Insensitivity to syntactic islands}

Hyperbaton is completely insensitive to syntactic islands and to locality-related conditions in Latin, another major problem if the movement takes place in the syntax.

\subsubsection{Insensitivity to the Coordinate Structure Constraint}

Ross's (1967) Coordinate Structure Constraint (CSC) bans movement of a conjunct out of a coordinate structure. Hyperbaton freely moves a left conjunct (for right conjuncts see 3.7):

\section{(35)}

sapientiae laudem [__ et eloquentiae]

wisdom $_{\text {GEN }}$ reputation $_{\mathrm{ACC}}$ and eloquence ${ }_{\mathrm{GEN}}$

'a reputation for wisdom and eloquence' (Cicero, de Oratione 2.363)

In 'both...and' structures we see 'both' dragged along with the fronted left conjunct:

(36) et carminibus edunt

both poems $\mathrm{ABL}_{\mathrm{ABL}}$ bring.out

'they bring out things in both their poems and their songs' (Cicero, Tusc. 471; D\&S 587)

This occurs with the clitic conjuction $=q u e$, too:

movement of the adjective. This will not generalize to $(\mathrm{N}, \mathrm{V}, \mathrm{A})$ heads that are not clitics yet evince the same patterns as Ps in Latin. Crucially for his analysis, adjectives can't move alone, nor may $\mathrm{P}+\mathrm{N}$ front, stranding the (otherwise) intervening adjective, nor may determiners move along with adjectives in the S. Slavic cases. All three cases are attested in Latin, as long as what has locally fronted forms (at least) a prosodic word.
(i) elicere nostros in locum conaretur [__ $]$ iniquum entice $_{\mathrm{INF}}$ our $_{\mathrm{ACC.PL}}$ into ground ${ }_{\mathrm{ACC}}$ try $_{3} \quad$ unfavorable $_{\mathrm{ACC}}$
'try to entice our men into unfavorable ground' (Caesar, Bello Gallico 8.16)
(ii) in sinu semper [__ $]$ et complexu meo in $\operatorname{arm}_{\mathrm{ABL}}$ always and embrace $\mathrm{ABL}_{\mathrm{ABL}}$ 'always in my arms and my embrace' (Cicero, Epistulae ad Familiares 14.4.3)
(iii) hoc tam gravi dignus [__ ] nomine this so heavy 'worthy of this so dignified name' (Cicero, de Oratione 1.64)


(37)

Faesulas inter $\left[\_\right.$Arretium $\left.=q u e\right]$

Faesulae $_{A C C}$ between $\quad$ Arretium $_{\mathrm{ACC}}$ and

'between Faesulae and Arretium' (Livy 22.3.3)

The CSC also bans movement from within a conjunct, and hyperbaton is not constrained by this either:

(38) legiones eduxit [duas et cohortes praetorias duas] legions $\mathrm{ACC}_{\mathrm{AC}}$ led.out $\mathrm{tWo}_{\mathrm{ACC}}$ and cohorts $\mathrm{ACC}_{\text {pretorian }} \mathrm{ACCO}_{\mathrm{ACC}}$ 'he led out two legions and two pretorian cohorts' (Cicero, ad Familares 10.30.1; D\&S 532)

Hyperbaton that breaks up coordinate structures in these ways is common (D\&S 586-591).

\subsubsection{Insensitivity to the Left Branch Condition}

Ross's (1967) Left Branch Condition (LBC) rules out extractions such as *Whose did you see book? Such extractions are commonplace in Latin:

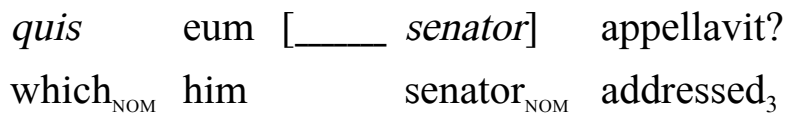

'Which senator addressed him?' (Cicero, ad Catilinam 6.12)

(40)
magna proponit eis qui
qui occiderint [
praemia]
great $_{\text {ACC.PL }} \operatorname{proposed}_{3}$ those $_{\text {DAT.PL }}$ who $_{\text {NoM.PL }} \operatorname{died}_{3 \text { P.P. .SUBJ }} \operatorname{rewards}_{\text {ACC.PL }}$
'proposes great rewards for those who died' (Caesar, Bello Gallico 58)

D\&S list a dozen syntactic categories that can undergo left branch extraction (2006: 542ff.). They make very clear the complete impotence of the CSC and LBC in Latin (2006: 524).

\subsubsection{Insensitivity to the Adjunct and Subject Conditions}

The Adjunct Condition bans movement from within adjuncts (Huang 1982, Chomsky 1986, Takahashi 1993). Hyperbaton ignores it: 
(41) de se ipsis et carminibus edunt [___et cantibus] about self $_{\mathrm{ABL}}$ same $_{\mathrm{ABL}}$ both poems $\mathrm{ABL}_{\mathrm{BL}}$ reveal $_{3 \mathrm{PL}}$ and songs $\mathrm{ABL}_{\mathrm{B}}$ 'revealed about themselves in both poems and songs' (Cicero, Tusc. 4.71)

This case simultaneously violates the CSC.

Nor is hyperbaton sensitive to the Subject Island (Ross 1967), a special case of the Adjunct Condition if subjects are adjuncts (Kayne 1994):
aqua restebat [__ et terra]

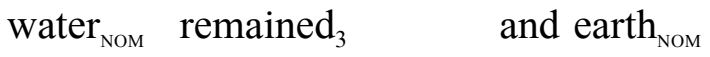
'water and earth remained' (Cicero, De natura deorum 2.66; D\&S 589)

This also ignores the CSC. Additional cases are not hard to find: Bello Civili 1.14, 1.50, 1.67, Bello Gallico 2.35, or the following case across a subject and a complementizer (from Spevak 2010):

$$
\begin{aligned}
& \text { naves interim Caesaris [onerariae errabundae __ ] } \\
& \operatorname{ships}_{\text {NOM.PL }} \text { meanwhile Caesar }_{\text {GEN }} \text { merchant }_{\text {NOM.PL }} \text { wandering }_{\text {NoM.PL }} \\
& \text { 'Meanwhile, Caesar's wandering merchant ships...' (Bello Africano }{ }^{5} \text { 21.3) }
\end{aligned}
$$

\subsubsection{Insensitivity to Freezing Islands}

Syntax doesn't move something out of a constituent that has already been moved; moved constituents constitute Freezing Islands (Wexler \& Culicover 1980). Hyperbaton ignores Freezing:

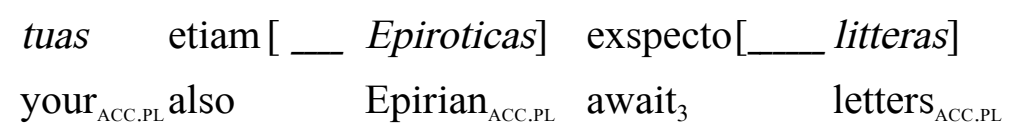

'I also await your letters from Epirus' (Cicero, ad Atticum 5.20.9; Spevak 2010)

Separate fronting of tuas and Epiroticas would violate cyclicity; if they fronted together it would front a non-constituent.

\footnotetext{
${ }^{5}$ Author disputed, but probably not Caesar.
} 


\subsection{Extremely local movement}

Extremely local movement within an XP is generally banned ('Anti-locality'; Grohmann 2002, Abels 2003, Kayne 2005). But the following moves the complement just to the left of the head:

domum reditionis spe [__

home $_{A C C}$ returning $_{G \mathrm{GN}}$ hope $_{\mathrm{ABL}}$

'with hope of returning home' (Caesar, Bello Gallico 1.5.3)

Extremely local movement is clearest when material lands between a head and its complement:

$$
\begin{aligned}
& {\left[\begin{array}{ll}
\text { ad impium }[\text { bellum }[ & \text { ac nefarium } \left.\left.\left.]_{\mathrm{AP}}\right]\right]_{\mathrm{NP}}\right]_{\mathrm{PP}} \\
\text { to impious } & \text { and wicked } \\
\text { ACC } & \text { war }_{\mathrm{ACC}}
\end{array}\right.} \\
& \text { 'to an impious and wicked war' (Cicero, in Catilinam 1.33) }
\end{aligned}
$$

Here impium has been fronted out of a coordinate structure past the noun it modifies [bellum] but not past the preposition whose complement it is part of. The only syntactic position after $a d$ and before bellum is [spec, NP], which is too local.

\subsection{Extremely distant movement}

Hyperbaton often moves prominent non-wh-material to the left of C:

$$
\begin{aligned}
& \text { de his rebus cum [_] ageretur apud Caesarem } \\
& \text { of these } e_{\mathrm{ABL}} \text { things } \mathrm{ABL}_{\mathrm{BL}} \text { when discussed }{ }_{\text {3PASS }} \text { with Caesar }{ }_{\mathrm{ACC}}
\end{aligned}
$$

'When it was discussed with Caesar about these things...'

(Caesar, Civili Bello 3.109; Pinkster 1990)

Hyperbaton can front direct and indirect objects, adjuncts, even small clauses:

(48) sin dormitet, ita dormitet, servom sese ut [cogitet ___]

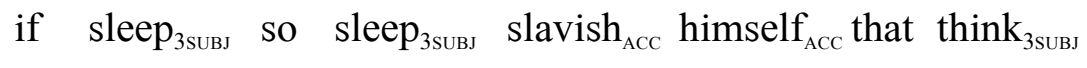

'If he should sleep, he should sleep in such a way that he thinks himself slavish.'

(Plautus, Aulularia 591)

Here the fronted material appears before $\mathrm{C}$, well to the left of the Topic and Focus positions 
usually posited in syntax (e.g., Rizzi 1997). This is fairly common in early Latin (Laughton 1960: 3).

Latin also moves material past relative pronouns in [spec, $\mathrm{CP}]$ :

$$
\begin{aligned}
& \text { huius quas dem [__ matri] } \\
& \text { her }_{\text {GEN }} \text { which }_{\text {ACC.PL }} \text { give }_{\text {3SUBJ }} \quad \text { mother }_{\text {DAT }} \\
& \text { 'which I could give to her mother' (Plautus, Asinaria 725) }
\end{aligned}
$$

Syntactically, this would require multiple distinct positions to the left of C.

\subsection{Movement past a coordinator}

Returning now to issues mentioned under the CSC, we consider movement past a coordinator. Coordinators generally sit between their conjuncts, so it is surprising to see that clitic $=q u e$ 'and' and =ve 'or' in Latin never surface there. Instead, they surface somewhere after the first word in the second conjunct:

$$
\begin{aligned}
& \text { (50) vir magni ingenii summa=que [__ prudentia] } \\
& \operatorname{man}_{\mathrm{NOM}} \text { great }_{\mathrm{ABL}} \text { talent } \mathrm{ABL}_{\mathrm{BL}} \text { superior }_{\mathrm{ABL}}=\text { and } \text { wisdom }_{\mathrm{ABL}} \\
& \text { 'a man of great talent and superior wisdom' (Cicero, Legibus 3.45) } \\
& \text { * vir magni ingenii }=\text { que summa prudentia }
\end{aligned}
$$

In [XP \& YP], there is no position within YP that precedes \&, yet this is precisely where things have moved to. The same problem applies to a lowering analysis: there is no position within YP for the coordinator to move to.

Movement of material past the clitic conjunctions $=q u e$ and $=v e$ is slightly different from hyperbaton because it doesn't necessarily involve discourse prominence on the material that is fronted. Instead, the movement is required by the coordinators themselves: these words cannot occur first in their phonological phrase, they are items Dover (1960) calls postpositives. Some of them are phonological clitics $(=q u e,=v e)$, some are not (autem 'however').

If the second conjunct consists of a single word, the coordinator appears after both conjuncts: 
(51)

$$
\begin{aligned}
& \text { oppida vicos }=\text { que } \\
& \text { towns }_{\mathrm{ACC}} \text { villages }_{\mathrm{ACC}}=\text { and } \\
& \text { 'towns and villages' (Caesar, Bello Gallico 1.28.3) } \\
& \text { * oppida = que vicos }
\end{aligned}
$$

(Similar cases in Caesar, Bello Gallico 1.2.1 and Frontinus, de Aquaeductu 1.18.). We take it as obvious that this cannot be syntactic movement; it is then either prosodic flip rightward (Halpern 1995) or another instance of the type of leftward phonological movement we are considering here.

In poetry (but never in prose) we find movement past non-clitic coordinators such as et 'and' and sed 'but':

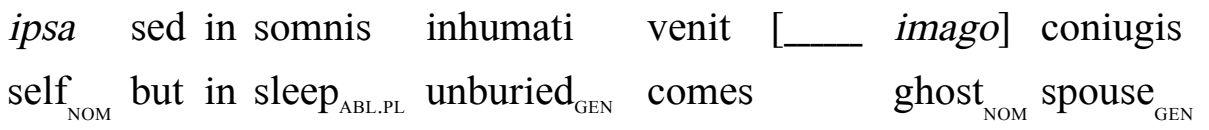

'but in her sleep comes the ghost itself of her unburied spouse' (Vergil, Aeneid 1.353-4)

Examples like this can be multiplied from the Aeneid alone, but we will look only at a few:

$$
\begin{aligned}
& \text { impius ex quo [__ Tydides] sed enim scelerum =que inventor Ulixes } \\
& \text { impious }_{\mathrm{NOM}} \text { from when Tydides }{ }_{\mathrm{NOM}} \text { but indeed evils } \mathrm{GEN}_{\mathrm{GEN}}=\text { and inventor }{ }_{\mathrm{NON}} \text { Ulysses }_{\mathrm{NOM}} \\
& \text { 'But indeed from when impious Tydides and Ulysses inventor of evils' (Aeneid 2.163-4) }
\end{aligned}
$$

The conjunction here is sed, the fifth word in: the PP ex quo 'from which (time)' has been fronted past it, as has the NP impius Tydides 'impious Tydides'. Note that impius has also been fronted past ex quo, so that impius Tydides is discontinuous; to make matters worse, impius Tydides is conjoined with scelerum inventor Ulixes 'Ulysses inventor of evils'.

The following lines show a number of the peculiarities of hyperbaton in a single passage. The first line involves fronting two adjectives (duri, magno) from distinct NPs past the sentential conjunction sed 'but': 
duri magno sed [__ amore] [__ dolores] polluto,

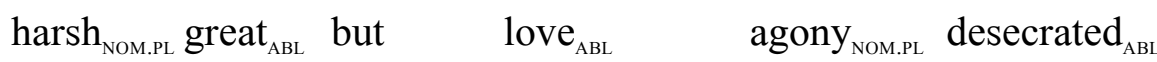

'but the harsh agonies, with a great love desecrated

notum $=$ que, furens quid [__ femina $]$ possit, known $_{\text {ACC }}=$ and raving 'and it being known what a raving woman can do,

triste per [__ augurium $]$ Teucrorum pectora ducunt.

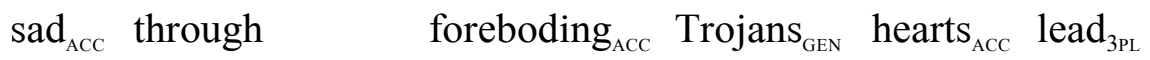
'led the Trojans' hearts through a sad foreboding' (Aeneid 5.6-8)

There is no syntactic position to the left of sed that could be accessible to material from the right conjunct; noone has ever proposed topicalizing or focusing material by moving it to the end of the preceding clause. The second line involves movement of the participle furens past the relative pronoun quid, which should itself be in [spec, CP] if this is syntactic. The third involves extremely local movement of triste past the preposition per. None of this looks like syntax.

We do not generally hold syntactic theory accountable for all the vagaries of poetic word order, but the data above should give us pause: these lines are all clearly serviceable and thus presumably not outside the realms of UG. Although they are not part of Latin prose (our focus here), they were produced and understood by Latin speakers and thus stand in need of some kind of analysis.

\subsection{Invisibility at LF}

Anaphors (reflexives and reciprocals) are generally preceded and c-commanded by their antecedents, but hyperbaton ignores this: 
(55) ne $s e_{\mathrm{i}}$ senatus $_{\mathrm{i}}$ in acta cuiusquam obligaret [_] not self senate NOM $_{\text {in }}$ acts $_{\text {ACC.PL }}$ someone $_{\text {GEN }}$ bind $_{3}$

'the senate should not bind itself to the acts of just any person'

(Suetonius, Tranquili vita Tiber 67)

LF is thus blind to hyperbaton, not something we expect of syntactic movement. ${ }^{6}$

\subsection{Partial movement}

Fanselow \& Lanertová (2012) 7 point out that Czech and German allow a subpart of a focused constituent to be moved. Specifically, these languages allow partial movement of just the leftmost accented part of the semantic focus. So to the question What did you do?, it is fine to answer with a discontinuous VP in German, where only the direct object is fronted:

(56) einen HAsen habe ich gefangen

$\mathrm{a}_{\mathrm{ACC}}$ rabbit $_{\mathrm{ACC}}$ have $\mathrm{I}_{\mathrm{NOM}}$ caught

'I caught a rabbit.'

Although the focus of the question is clearly on the whole VP (What did you do?), (56) has only a subpart of the focus fronted, with the focused verb remaining in situ. Fanselow \& Lanertová argue that this makes little sense if the movement is driven by syntactic featurechecking, since we would then expect full fronting of the focused constituent rather than partial. They therefore reject analyses such as Rizzi's (1997) that have focus and topic positions in the syntax, and adopt Chomsky's (2008) view that there is no direct link between syntax and information structure.

Hyperbaton can be partial too, casting more doubt on its being syntactic: in what D\&S call postmodifier hyperbaton, for instance, the leftmost element (here the adjective) is stranded in situ, but the entire XP is still generally focused (D\&S 2006: 531ff.):

$\begin{array}{llll}\text { legiones conscripsit [novas___ } & \text {, excepit veteres } \\ \text { legions }_{\text {Acc.PL }} & \text { enlisted }_{3} \quad \text { new }_{\text {Acc.pL }} & \text { took.over } & \text { old }_{\text {Acc.pL }}\end{array}$

'He enlisted new legions, and took over old ones.' (Cicero, Philippics 11.27)

\footnotetext{
${ }^{6}$ Saito 1989 provides evidence that long-distance scrambling, argued to be syntactic, is vacuous with respect to LF binding; note, however, that these 'radical reconstruction' effects occur across the board for hyperbaton in Latin, whether it is local or long-distance.

${ }^{7}$ We thank an anonymous reviewer for directing us to this article.
} 
contionem habuit [maximam

meeting $_{\mathrm{ACC}}$ held $_{3}$ largest $_{\mathrm{ACC}}$

'He held a very large meeting' (Cicero, Philippics 14.16)

If Fanselow \& Lanertová are correct, partial movement is fatal for a syntactic analysis based on feature checking or the like: whatever forces movement of an XP to the focus position should prohibit partial movement.

\subsection{Focus and topic in situ}

Fanselow \& Lanertová also argue that focalization and topicalization in situ are incompatible with syntactic movement. German allows an unfocused subject to be moved while a focused object is left in situ. The following is a good answer to 'What did you do?':

Ich habe einen HAsen gefangen

$\mathrm{I}_{\mathrm{NOM}}$ have $\mathrm{a}_{\mathrm{ACC}}$ rabbit $_{\mathrm{ACC}}$ caught

'I caught a rabbit.'

They argue that an analysis based on feature checking cannot account for in situ focalization or topicalization. Latin allows in situ focus too:

(60) non solum regem sed regnum de re publica sustulissem not only king $_{\text {acc }}$ but kingship $p_{\text {abl }}$ from state ${ }_{\text {abl }}$ removed $_{1 \text { subj }}$ 'I would have removed not only the king but also the monarchy from the state' (Cicero, Philippics 2.34)

D\&S discuss a number of cases like this in which 'the strong focus does not move to the preverbal FocVP position but apparently stays in situ' (2006: 229, cf. p. 232). ${ }^{8}$

Thus we find three ways to focus something in Latin: move it, move part of it, move none of it. Only the first of these makes syntactic sense.

\subsection{Superiority}

Languages that allow only one wh-phrase to move require the structurally higher one to move (Chomsky 1973), and languages that allow multiple cases of wh-movement within a clause

\footnotetext{
${ }^{8} \mathrm{D} \& \mathrm{~S}$ note that such cases could also result from string vacuous movement, perhaps through scrambling to an argument position, though this raises a number of semantic issues (2006: 232).
} 
generally require that the structurally higher one precede any structurally lower ones. This is known as superiority (Chomsky 1973). D\&S (2006:89) and Danckaert (2012:244-253) note that superiority appears to hold for rare cases of multiple wh-movement in Latin :

(61) ego quid $_{\mathrm{i}}$ cui $\mathrm{i}_{\mathrm{j}}$ debeam []$_{\mathrm{i}}[]_{\mathrm{j}}$ scio

I what $_{\mathrm{ACC}}$ whom $_{\mathrm{DAT}}$ owe $_{1 . \text { SUBJ }} \quad$ know $_{1}$

'I know what I owe to whom' (Seneca, de Beneficiis 4.32.4)

But they note that Latin has a set of mostly homophonous indefinites that need not obey superiority:

$$
\begin{aligned}
& \text { si } \left.\text { cui }_{j} \quad \text { quid }_{i} \quad \text { ille promisit [_ }\right]_{\mathrm{i}}[]_{\mathrm{j}} \\
& \text { if } \text { someone }_{\text {dat }} \text { something }_{\text {acc }} \text { he } \text { nom }_{\text {promised }} \text { pff }
\end{aligned}
$$

'if he promised something to someone' (Cicero, Phil 1.17; Danckaert 2012:249 fn. 16))
(63) ut ne cui $i_{\mathrm{j}} \quad$ quis $_{\mathrm{i}} \quad$ noceat $\quad[]_{\mathrm{i}}[]_{\mathrm{j}}$ that not someone $_{\text {dat }}$ someone $_{\text {nom }}$ do.harm ${ }_{1 \text { subj }}$ 'that someone not do harm to someone' (Cicero, Off 1.20; D\&S 2006:89)

Though it appears from scant evidence (61) that movement of wh-words may be sensitive to superiority, there is very little data to base a firm conclusion on. If it is assumed that whwords respect superiority even when they function as indefinites, the last two cases are problematic for a syntactic analysis.

\subsection{Split Names}

Hyperbaton can break up a proper name (D\&S 2006:272ff):

(64) M. ad me Brutus, ut consueverat, cum T. Pomponio venerat [__

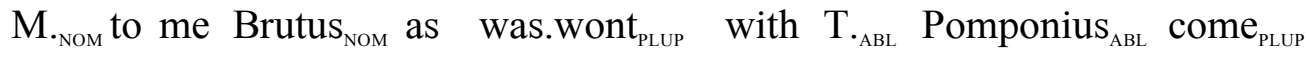
'Marcus Brutus had come to me, as he was wont, with Titus Pomponius' (Cicero, Brutus 3.10)

Here the subject is interrupted by material (ad me) that has been fronted from much lower in the clause. We know of no syntactic analysis of proper names that includes a focus or topic 
position inside a name, so this kind of movement seems especially difficult for syntax. ${ }^{9}$

It's also possible to move the first half of a name leftwards (D\&S 2006:272ff):

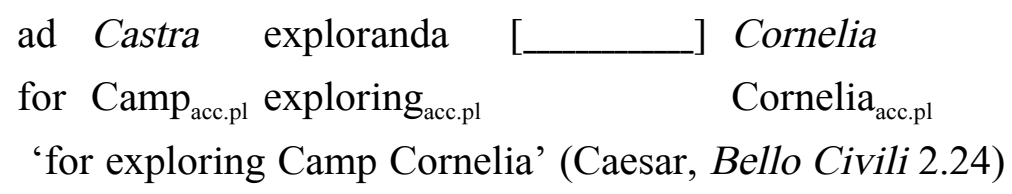

This is surprising if the movement is syntactic, because names are generally treated as syntactic terminals (but see Bošković 2009).

The peculiar properties of hyperbaton we have just seen make syntactic analyses of it difficult or impossible, given the usual limitations on how syntax works. We turn now to a number of properties of hyperbaton that are surprisingly phonological in character.

\subsection{Movement of prosodic constituents}

Lexical heads map onto prosodic words in the phonology, usually carrying any preceding functional heads or following pronouns with them (Selkirk 1984, 1986). We have already seen a number of cases where a single lexical head moves; each of these is a prosodic word, so the apparent movement of a head in syntax can equally well be movement of a prosodic word in phonology. We also saw simple and complex cases of apparent XP movement; since XPs in syntax map onto phonological phrases in phonology, all of these can also be seen as moving phonological phrases. When syntactic heads and phrases are coextensive with prosodic words and phonological phrases, it is difficult to decide which has undergone movement: was a syntactic constituent moved or was it a phonological constituent?

We showed above that many of the strings that are moved in hyperbaton are not syntactic constituents $(\S 3.3)$. They are, however, prosodic constituents, either prosodic words

${ }^{9} \mathrm{Cal}$ Watkins (personal communication) alerted us to a line attributed to Ennius, where the noun cerebrum 'brain' is split apart by the verb comminuit 'smashed'.

saxo cere comminuit brum

rock $_{\mathrm{ABL}}$ cere- smashed $\quad$ brum $_{\mathrm{ACC}}$

'He smashed his brain (cerebrum) with a rock.' (Ennius fr. 609)

A related case may be Cicero's (prose)

per mihi mirum visum est

very- $\mathrm{me}_{\mathrm{DAT}}$ strange seen is

'appeared very strange to me' (de Oratore 1.214)

where prefixed permirum (normally one word) is split by the insertion of mihi 'to me'. 
or phonological phrases. In the simplest case, we see nothing moved, as below where we indicate prosodic words with $\omega$ (note that the preposition in is treated just as a foot and that it and the relative pronoun qua form a recursive prosodic word, which itself forms a recursive prosodic word with the following content word re 'matter'):

(66) $\left(\left(\text { in } q u a_{\omega}\right)_{\omega} \quad r e_{\omega}\right)_{\omega} \quad$ virtus $\quad$ militum...

in which $_{\mathrm{ABL}}$ matter $_{\mathrm{ABL}}$ bravery $_{\mathrm{NOM}}$ soldiers $_{\mathrm{GEN}}$

'in which matter the bravery of the soldiers...' (Caesar, Bello Gallico 5.8)

Below we see the same phrase undergoing hyperbaton: qua 'which' is fronted past the preposition, suggesting that it forms its own prosodic word separate from both in and $\mathrm{re}_{\omega}$ :

$$
\begin{aligned}
& q_{\omega} \quad\left(\text { in }-\mathrm{re}_{\omega}\right)_{\omega} \quad \text { Caesar } \quad \text { non } \quad \text { solum... } \\
& \text { which }_{\mathrm{ABL}} \text { in } \text { matter }_{\mathrm{ABL}} \text { Caesar }_{\mathrm{NOM}} \text { not } \text { only } \\
& \text { 'in which matter Caesar not only...' (Caesar, Bello Gallico 1.12) }
\end{aligned}
$$

If the PP in qua re were a simple prosodic word with no recursion, it's hard to see how qua could be fronted without dragging the rest along. We assume that when qua is fronted (67), in is forced into a recursive prosodic word with what now follows, re 'matter'. Fortson (2008:112-117) provides evidence from meter that the preposition in such cases does indeed form a prosodic unit with the following word (re) rather than the preceding word (qua); for evidence that such magna cum laude constructions involve fronting (of magna) rather than postposing (of cum), see Fortson (2010).

In many cases, the string that moves in hyperbaton is simply a function word followed by a content word, as below, where movement of per Graecas 'by Greek' strands sacerdotes 'priestesses':

$$
\begin{aligned}
& \left(\text { perGraecas }_{\omega}\right)_{\omega} \text { curata sunt semper [___ sacerdotes] } \\
& \text { by } \text { Greek }_{\mathrm{ACC}} \text { carried.out }_{\mathrm{NOM}} \operatorname{are}_{3 \mathrm{PL}} \text { always } \text { priestesses }_{\mathrm{ACC}} \\
& \text { 'and are always carried out by Greek priestesses' (Cicero, Pro Balba 55) }
\end{aligned}
$$

These provide some of the clearest cases for phonological movement because the prosodic word doesn't correspond to any syntactic constituent. This can involve more than one function word: 
$\left(\left(\mathrm{ex} \quad h i s_{\omega}\right)_{\omega} \quad \text { omnibus }_{\omega}\right)_{\omega}$ iudicat $(\ldots \text { rebus })_{\varphi}$ from $_{\mathrm{ABL}}$ these $_{\mathrm{ABL}}$ other $_{\mathrm{ABL}} \quad$ judges $_{3} \quad$ things $_{\mathrm{ABL}}$

'from all these other things he forms a judgment'

(Caesar, Bello Gallico 5.52; D\&S 2006:573)

Here the function words form a recursive prosodic word that itself forms a recursive prosodic word with the following content word; and this maximal recursive prosodic word is fronted past the verb, stranding the head noun. If movement always involves constituents, it must be phonological constituents in such cases, since the syntactic constituency is [ex [his [omnibus rebus]]] where ex his omnibus is not a syntactic constituent of any kind.

Alternatively, the prosodic word can be just a content word on its own, part of a larger phonological phrase, like ceteris 'other':

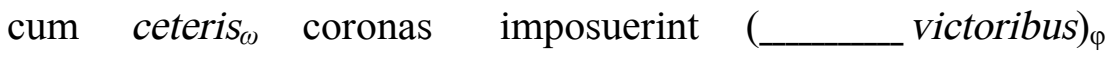

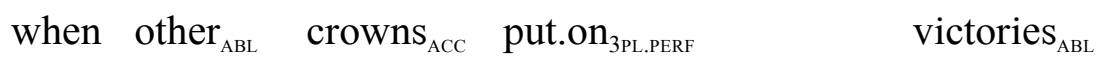

$$
\begin{aligned}
& \text { 'when they've put crowns on the other victors' (Cicero, ad Familiares 5.12.8) }
\end{aligned}
$$

Movement of phonological phrases is also common: we have seen it already with multiword XPs $(30,45,48)$, in one-word XPs $(35,37,42,43,46,47)$, and with fronted PPs $(\$ 3.15)$. When the entire complement is fronted, its prosodic size depends on whether it is lexical or not. If it is a non-lexical XP we assume that it is just a prosodic word (recall that all words in Latin are subect to a $\mu \mu$ minimum): this includes many left branch cases, subject and object pronouns, closed-class adverbs, and so on. If what is moved corresponds to a lexical NP, VP, or AP, it is likely a phonological phrase, as we saw with subjects, direct objects, VPs, and so on. In all such cases it is of course difficult to know whether the moved constituent is syntactic (XP) or prosodic $(\omega, \varphi)$, and the decision must be made on other grounds: we have argued above that many kinds of hyperbaton cannot be syntactic for various reasons, so we assume here that it is generally phonological and that what appear to be cases of XPs moved in the syntax are actually $\varphi s$ moved in the phonology. Whether higher levels of the prosodic hierarchy ever move is something we are not prepared to address here.

Assuming that conjunctions, complementizers, and (monosyllabic) prepositions are just feet and not prosodic words (§2), we may say that phonological movement in Latin targets $\omega$ and $\varphi$ but nothing smaller, just as syntactic movement generally targets $\mathrm{X}^{0}$ and $\mathrm{XP}$ but nothing smaller. ${ }^{10}$ We note that this cannot be a general property of phonological movement, however,

\footnotetext{
${ }^{10}$ We assume that apparent cases of $\mathrm{X}^{\prime}$ movement are actually XP movement, following Speas 1990 and Carnie 2010: 136ff.
} 
since Irish allows phonological movement of syllables (Bennett, Elfner and McCloskey to

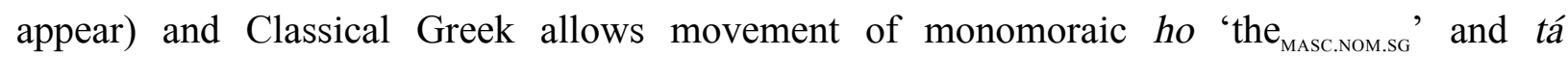
'the NEUT.Nom.SG ' (Agbayani \& Golston 2010b), but it does seem to be a property of phonological movement in Latin.

\subsection{Second position phenomena}

D\&S consider a number of 'second position' particles that bring about discontinuous constituency, including sentential connectives like autem 'for' and=que 'and', as well as focusing particles like quoque 'also' and quidem 'even'. Since Wackernagel (1892), these have been treated separately from hyperbaton, in part because second position particles require movement, while focalization and topicalization merely allow it. We follow Agbayani \& Golston 2010ab in treating both as phonological movement: hyperbaton is conditioned by focalization and topicalization as we have seen, while second-position placement is required by certain particles that may not be initial in a phonological phrase (see 3.7 above). In Dover's terminology (1960), they are postpositive, subject to the following condition in the postsyntactic phonology (Agbayani \& Golston 2010a:160):

\section{PostPos: No postpositive is initial in its $\varphi$.}

Thus quidem 'even' has scope over the entire PP ex qua re 'from which thing' in the following but it cannot be initial in its phonological phrase, so instead of *quidem ex qua re we find:

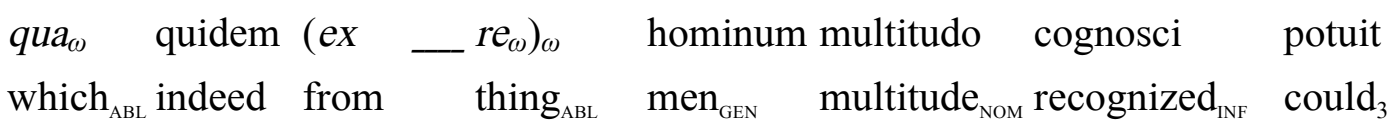
'From which thing indeed a multitude of men could be recognized' (Caesar, Bello Gallico 5.42)

For Halpern 1995, D\&S 2006, and others this kind of movement involves 'flipping' quidem and qua, or lowering quidem into the PP, all of it done after the syntax proper; we leave quidem in situ and move qua to its left, using the same phonological movement we propose for hyperbaton. As evidence that this is the same type of movement found with hyperbaton, we note that it has the same insensitivity to islands and so on found with hyperbaton, as we will now see.

Second position sentential connectives like enim 'for', autem 'but, however', and vero 'as for' exemplify how similar second position phenomena are to hyperbaton in their un- 
syntactic behavior (see D\&S 2006:266-277 for discussion, from which we take the following three examples). Note from the gloss below that autem has scope over the NP it sits within:

$$
\begin{aligned}
& \text { princeps autem [__ civitatis }] \\
& \text { first }_{\mathrm{NOM}} \text { but } \text { citizenry }_{\mathrm{GEN}} \\
& \text { 'but the first of the citizens...' (Cicero, post reditum in Senatu 4) }
\end{aligned}
$$

It can also split a proper name (74), move a left branch (75), move something out of a coordinate structure (76), or move a prosodic word that isn't a syntactic constituent (77):

$$
\begin{aligned}
& \begin{array}{ll}
P . & \text { autem }[ \\
\mathrm{P}_{\text {NOM }_{\mathrm{NO}}} \text { but } & \text { Vatinius }] \\
\text { Vatinius }_{\mathrm{NOM}}
\end{array} \\
& \text { 'but Publius Vatinius...' (Cicero, Philippics 10.13) }
\end{aligned}
$$

$$
\begin{aligned}
& \begin{array}{lll}
\text { dolus } & \text { autem } \\
\text { criminal }_{\mathrm{NOM}} \text { however } & {\left[\begin{array}{l}
\text { malus } \\
\text { fraud }_{\mathrm{NOM}}
\end{array}\right.}
\end{array} \\
& \text { 'but criminal fraud' (Cicero, de Officiis 3.61; D\&S 273) }
\end{aligned}
$$

$$
\begin{array}{ll}
\text { populo autem [__ et Pompeio }] \\
\text { people }_{\mathrm{ABL}} \text { but }
\end{array}
$$

'but from the people and Pompey' (Cicero, ad Atticum 1.19)

(77) ex quattuor autem [_ locis $]$

of four $_{\mathrm{ABL}}$ but divisions ${ }_{\mathrm{ABL}}$

'but of the four divisions [we have made]' (Cicero, de Officiis 1.6)

All of this suggests that the placement of autem and similar words is dependent on phonology, either in whole or in part (see D\&S 2006:275ff).

\subsection{Hyperbaton blocked by homophony}

Hyperbaton is blocked if it would bring together homophonous function words within a prosodic word. ${ }^{11}$ The blocking comes about when a PP headed by the preposition cum 'with' is fronted in a subordinate clause headed by the complementizer cum 'when'. We expect to find clauses that begin cum cum 'when with...', but none occur, showing that the fronting is

\footnotetext{
${ }^{11}$ Something similar has been discussed for Ancient Greek (Smyth 1920, §1162; Golston 1995), but not for Latin, as far as we know.
} 
blocked. The argument is only interesting, of course, to the extent that the string cum cum would otherwise be expected, so this section will show that it should be common based on the ubiquity of other complementizers and PPs.

PPs are fronted quite regularly in Latin, not only in matrix but also in subordinate clauses. This results in complementizer + preposition strings like cum ad 'when to' or ut cum 'so that with':

(78) ut cum L. Aemilio Caeso Fabius consul crearetur [___

so.that with L. Aemilius ABL $_{\text {Caesus }}$ ABL $_{\text {Fabius }_{\text {NOM }}}$ consul made $_{3 . \text { PAss.SuBJ }}$

'so that Fabius was made consul with L. Aemilius Caesus' (Livy 42)

To gauge how common this is, we searched for strings with ut 'so that' plus various prepositions and found that all combinations are attested in all but two authors (Frontinus has no ut cum and Sallust has no ut ad, probably due to their relatively small corpora):

$\begin{array}{lrrrrr} & \text { ut in } & \text { ut ad } & \text { ut } a b & \text { ut ex } & \text { ut cum } \\ \text { Caesar } & 48 & 14 & 16 & 14 & 8 \\ \text { Cicero (letters) } & 80 & 85 & 31 & 22 & 24 \\ \text { Cicero (philosophy) } & 246 & 73 & 74 & 60 & 55 \\ \text { Cicero (speeches) } & 112 & 53 & 56 & 32 & 29 \\ \text { Frontinus } & 13 & 8 & 4 & 6 & 0 \\ \text { Livy } & 23 & 3 & 4 & 4 & 4 \\ \text { Pliny Younger } & 40 & 4 & 10 & 10 & 5 \\ \text { Sallust } & 3 & 0 & 1 & 2 & 2 \\ \text { Seneca Elder } & 19 & 10 & 5 & 5 & 4 \\ \text { Suetonius } & 19 & 13 & 8 & 8 & 5 \\ \text { Tacitus } & 41 & 10 & 2 & 6 & 4 \\ \text { Varro } & 144 & 6 & 65 & 21 & 9\end{array}$

Table 1. ut 'so that' plus various prepositions in a number of prose authors.

Crucially, none of the columns in Table 1 is underpopulated. The same goes for the complementizer cum 'when' (Table 2), except when it is followed by the homophonous preposition cum 'with', in which case the number of occurrences suddenly drops to zero in every author: 


$\begin{array}{lrrrrr} & \text { cum in } & \text { cum ad } & \text { cum ab } & \text { cum ex } & \text { cum cum } \\ \text { Caesar } & 41 & 31 & 22 & 11 & 0 \\ \text { Cicero (letters) } & 43 & 54 & 39 & 16 & 0 \\ \text { Cicero (philosophy) } & 136 & 55 & 57 & 52 & 0 \\ \text { Cicero (speeches) } & 128 & 38 & 54 & 31 & 0 \\ \text { Frontinus } & 14 & 6 & 12 & 7 & 0 \\ \text { Livy } & 13 & 7 & 3 & 0 & 0 \\ \text { Pliny Younger } & 11 & 6 & 2 & 8 & 0 \\ \text { Sallust } & 2 & 3 & 2 & 1 & 0 \\ \text { Seneca Elder } & 17 & 11 & 3 & 1 & 0 \\ \text { Suetonius } & 14 & 9 & 4 & 9 & 0 \\ \text { Tacitus } & 10 & 4 & 3 & 7 & 0 \\ \text { Varro } & 20 & 11 & 11 & 9 & 0\end{array}$

Table 2. cum 'when' plus various prepositions in a number of prose authors.

Put another way, we find nothing like the following anywhere in Latin:

$$
\begin{aligned}
& \text { (79) * cum cum Phania loquerer } \\
& \text { when with Phania } \text { ABL }_{\text {speak }} \text { 1.MpP.SUBs } \\
& \text { 'when I was speaking with Phania' [construct] }
\end{aligned}
$$

Cases are attested where material appears between cum the complementizer and cum the preposition:

(80) cum loquerer cum Phania
when speak $_{1 . \mathrm{IMPF} . \mathrm{SUBJ}}$ with Phania
'wBL
'when I was speaking with Phania' (Cicero, ad Familiares 3.5.1)

Thus there is no issue with a PP headed by cum in a clause headed by cum; it is just that cum and cum cannot appear next to each other.

Since the two instances of cum in these cases are morphosyntactically distinct but phonologically identical, we assume that what keeps them from showing up next to each other is an instantiation of the OCP (Leben 1973). Similar bans on adjacent homophonous function words are found in French (Radford 1977), Ancient Greek (Golston 1995), Mandarin (Yip 1998), Dutch (Ackema 2001), Russian (Agbayani et al 2011), and Ukrainian (Teliga 2011); see Nevins 2012. The OCP should not block syntactic movement if syntax is phonology-free (Zwicky \& Pullum 
1986ab), ${ }^{12}$ but it should block phonological movement, and does.

\subsection{Hyperbaton blocked by syllable count}

One of the commonest types of hyperbaton in Latin is the magna cum laude type familiar from graduation ceremonies, in which an adjective (magna) is fronted past a preposition (cum), stranding the rest of the NP (laude). Another common case is:

$$
\begin{aligned}
& \text { (81) ulla ex parte } \\
& \text { any }_{\mathrm{ABL}} \text { from part }{ }_{\mathrm{ABL}} \\
& \text { 'from any part' }
\end{aligned}
$$

Although part of a lexically headed NP can be fronted in a PP, there is a restriction on fronting all of the NP. If the preposition is monosyllabic, it cannot be stranded PP-finally: ulla ex parte is good but *ulla parte ex is completely unattested in prose.

Significantly, it is possible to get this order with polysyllabic prepositions like super, cf. humum super 'on (the) ground' (Tacitus, Annales 16.35), as discussed in Fortson (2010: 139). ${ }^{13}$ The facts are matched by suprisingly similar data in contemporary Russian (Henderer 2010:9) and Ukrainian (Teliga 2011: 21ff): PPs can only end in P if it is polysyllabic. In all three languages, then, hyperbaton stranding a preposition is blocked if the $\mathrm{P}$ is monosyllabic, a purely phonological restriction.

\section{Analysis}

We turn now to two extant analyses of hyperbaton in Latin, both of them syntactic, and to analyses of similar phenomena in other languages that might be extended to Latin. We show that these analyses all fail in one way or another to model hyperbaton in Latin (4.1). We then propose an analysis based on phonological movement and prosodic recursion (4.2).

\subsection{Hyperbaton as syntactic movement}

In an extensive study of Latin word order, D\&S 2006 propose that Latin has Topic and Focus projections above every XP, so that hyperbaton can move material to two distinct positions at the edge of any phrase:

\footnotetext{
${ }^{12}$ We agree with Zwicky \& Pullum that syntax is phonology-free; we disagree that all movement is syntactic.

${ }^{13}$ We thank an anonymous reviewer for bringing this to our attention.
} 
One of the characteristic features of Latin syntax is that it has pragmatically defined functional projections superordinate to XP which are crosscategorial. We define these as FocXP and TopXP. FocXP is a focus position local to the phrase XP, and TopicXP is a topic (subject) position local to the phrase XP. (2006:25)

Their complete model is as follows, with little structure above the complementizer but a large amount of additional structure below it (2006:27-28):

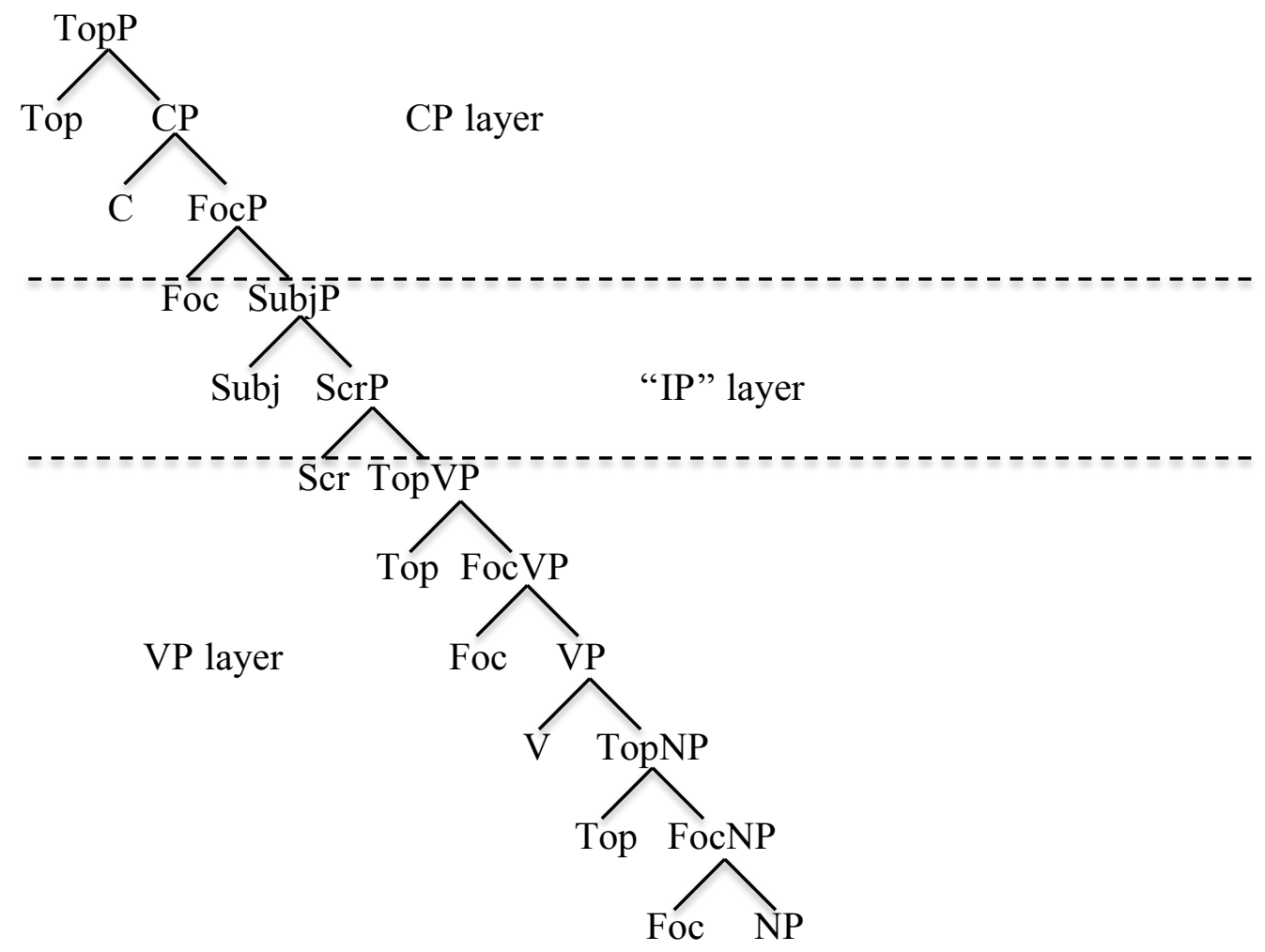

Although it isn't clear from the tree above, D\&S allow multiple FOC and TOP positions for a single XP, e.g., [TopNP $[$ FocNP $[$ TopNP $[$ FocNP $[\mathrm{NP}]]]]$ (2006: 490). This proliferation of crosscategorical topic and focus projections solves the issue of category neutrality discussed above (3.1); if we allow heads to move to FOC and TOP positions and phrases to move to their spec positions, the fact that hyperbaton targets both $\mathrm{X}^{\circ}$ and $\mathrm{XP}$ (3.2) can be handled as well; the issue of extremely local movement (3.5) is also solved since movement to FoC and TOP positions falls outside of the minimal XP in which a phrase originates; and it allows for fronting to the left of a complementizer (3.6).

The many FOC and TOP positions would seem to allow for many positions for foci and topics to occur in, and something like this richness does indeed occur. Consider ea 'those' in the following, where it occurs in situ (a), or fronted past a verb (b), direct object (c), adverb + verb (d), or clause (e). The first case involves no movement, so if there is focus, it is focus in 
situ; the second presumably involves successive cyclic movement on D\&S's analysis through $[\mathrm{FoC}, \mathrm{NP}]$ to $[\mathrm{Foc}, \mathrm{VP}]$ :

$$
\begin{aligned}
& \text { a. } \begin{array}{llll}
\text { iter } & \text { in }\left[\begin{array}{lll}
\text { ea } & \text { loca }
\end{array} \quad\right. \text { facere } & \text { coepit } \\
\text { march }_{\mathrm{ACC}} \text { in those } & \text { ACC.PL } \text { areas }_{\mathrm{ACC} . \mathrm{PL}} & \text { direct }_{\mathrm{INF}} & \text { began }_{3 \mathrm{SG}}
\end{array} \\
& \text { 'began to direct his march into those areas' (Caesar Bello Gallico 4.7.1) }
\end{aligned}
$$

b. qui tum ea tenebant [_loca $]$

who $_{\text {NOM.PL }}$ then those ACC.PL $_{\text {occupied }}$ 3PL areas $_{\text {ACC.PL }}$

'who then occupied those areas' (Livy 1.1.5)

c. quin ea me [__ cura $]$ vehementissime sollicitet that.not this $\mathrm{NOM}_{\mathrm{NOM}}$ me trouble ${ }_{\mathrm{NOM}}$ most.vehemently $_{\mathrm{ACC.PL}}$ disturbs $_{3}$ 'that this trouble doesn't disturb me most vehemently' (Cicero ad Familiares 2.16.5)

d. ea denique videtur [_ condicio $]$ impendere that $_{\mathrm{NOM}}$ finally seems $_{3 \mathrm{~s}} \quad$ condition $_{\mathrm{NOM}}$ be.imminent $\mathrm{INF}_{\mathrm{IN}}$ 'finally, that condition seems to be imminent' (Cicero ad Familiares 5.18.1)

e. ea profugus ex Peleponneso auctoritate magis quam imperio those $_{\text {ACC }}$ exiled $_{\text {NOM }}$ from Peleponnese $e_{\text {MASC.ABL }}$ authority FEM.ABL $_{\text {more than }}$ power FEM.ABS $_{\text {. }}$

$\begin{array}{ll}\left.\begin{array}{ll}\text { regebat } & \text { loca }]\end{array}\right] \\ \text { ruled }_{3 . \mathrm{IMPF}} & \text { areas }_{\mathrm{ACC}}\end{array}$

'exiled from the Peleponnese, he ruled those areas more by authority than power' (Livy 1.8)

But the other cases are problematic. (c) fronts the left branch (ea) of the subject past a pronominal object me 'me' that must itself have been fronted (it is the object of sollicitet 'disturbs'); the problem is that D\&S have only a single position between the subject and the complementizer (filled by quin in c), so it's unclear where ea and me could be moved to. Similarly in (d): if cura remains in the subject position, three things (ea, denique, and videtur) have been fronted past the subject into just two positions, the ToP position above $\mathrm{C}$ and the FOC position below it. These problems might be solved with additional FOC and TOP projections, but that still leaves other problems: (c) and (d) ignore the Subject Condition and (b)-(e) ignore the LBC. A difficult question for any analysis comes from comparing (b) and (e). If (b) satisfies whatever it is that drives fronting, why does (e) move ea so much farther, 
not just past the verb (regebat), but all the way to the beginning of the clause?

In any case, the additional structure does not address how hyperbaton moves strings that aren't syntactic constituents (3.3); why it is blind to islands that usually block syntactic movement (3.4) and is semantically vacuous at LF (3.8); why it sometimes moves only part of a focused or topicalized constituent (3.9) and is generally optional (3.10); or how it can ignore the superiority condition (3.11) and split apart names (3.12). Although D\&S discuss the word order of both prose and poetry at length, the model above cannot account for movement to the left of a sentential conjunction in poetry (3.7), as their FOC and TOP projections don't extend above CP. The tree above also fails to cast any light on the phonological properties of hyperbaton: moved strings are either prosodic words or phonological phrases (3.13); hyperbaton is required by 'second position' particles (3.14); and it is blocked when it would bring together adjacent homophones within a prosodic word (3.15) or would end a phonological phrase with less than a prosodic word (3.16). These things require a more active role of prosody than their core analysis admits.

Danckaert 2012 adds additional FoC and Top projections to those of D\&S and in so doing captures some types of data that their model fails to get. Specifically, Danckaert proposes a rich left periphery above the complementizer ( $\mathrm{C}$ in the tree below; 2012: 280):
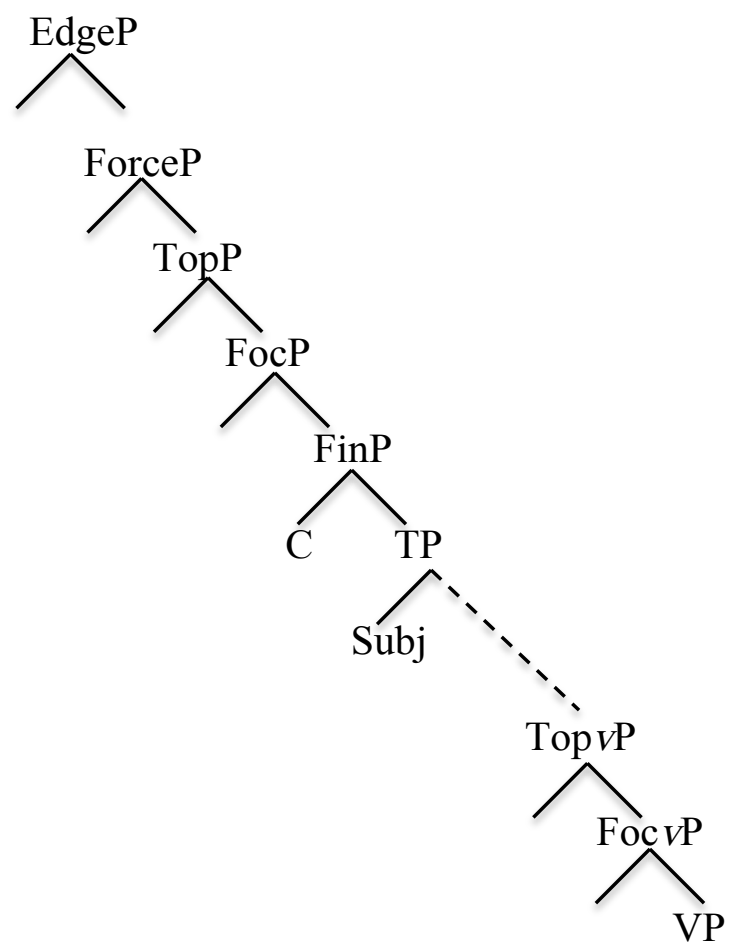
Danckaert's model allows multiple XPs before the complementizer, ${ }^{14}$ which the D\&S model doesn't, but it otherwise falls short in the same ways that the D\&S model does. We move on now to models that were not originally designed for Latin.

The important issue of non-constituent fronting (3.3) has received much attention in syntax and we need to see here if the proposals made there can be extended to cover the Latin facts. Non-constituent fronting is attested in some Slavic languages, particularly with 'split' PPs (Franks \& Progovac 1994; Bašić 2004; Bošković 2005). An influential approach to such data is scattered deletion (Ćavar \& Fanselow 2000, Nunes 2004), which uses multiple feature checking positions for syntactically moved constituents whose material is spelled out discontinuously at these different positions. Discontinuously spelling out material is determined by purportedly phonological conditions on the expression of copies in multiple syntactic checking positions. The conditions require upper copies to be spelled out discontinously, and the lowest copy to be deleted.

Another approach base generates the 'fronted' material and then lowers it back into thematic positions at LF (see Bošković \& Takahashi 1998 for Japanese scrambling). Applied to Latin, it would address the semantic vacuity of hyperbaton at LF (3.8), which is also a property of so-called A-bar scrambling in Japanese (Saito 1989). But it is unclear what the motivation for LF lowering would be in Latin, especially in the many cases where theta assignment is not relevant. For example, we have seen that quantifiers, demonstratives, adjectives and non-constituent strings like Dem + Adj or Prep + Adj are fronted. In these cases, there is no interpretive property that would require lowering into the regular constituent position. Perhaps most problematic for a base generation with lowering analysis are cases of non-constituent string fronting in PP splitting cases (eg, 4), in which a preposition and part of the left branch of the complement NP are fronted. We don't see how or why P+Adj would be assembled together from a lexical array in the first place, then base-generated in a fronted position in syntax, then lowered at LF for interpretation.

${ }^{14}$ Danckaert (2012) observes that certain cases of leftward movement past a complementizer in adverbial subordinate clauses are associated with presentational focus. His analysis places the fronted material in the [spec, FocusP] position of an articulated syntactic left periphery to the left of the complementizer, expanding the "cartographic" approach to clausal architecture of Rizzi 1997. But in Rizzi's system, FocusP in the clausal left periphery is associated typically with identificational ('only' or 'exhaustive' focus), not with presentational (new information), focus. This makes the syntactic left periphery an unlikely position for presentational foci like we get in Latin. Presentational focus is typically associated with immediate VP-external position within the clause, and appears to extend to extremely local fronting cross-categorially. 
Thus, scattered deletion can capture non-constituent movement (3.3) and base-generation can address semantic vacuity (3.8). But these approaches fail to address category and bar-level neutrality (3.1-2), insensitivity to islands (3.4), extremely local movement (3.5), fronting to the left of a complementizer (3.6) or conjunction (3.7), partial and optional movement (3.9-10), insensitivity to the superiority condition (3.11), name-splitting (3.12) or any of the phonological aspects of hyperbaton (3.13-16).

\subsection{Hyperbaton as phonological movement}

We propose that hyperbaton in Latin moves discourse-prominent $\omega$ and $\varphi$ within prosodic trees, with no direct reference to syntactic features, categories, or constituents of any kind. Hyperbaton simply fronts a $\omega$ or $\varphi$ to the left edge of some $\omega, \varphi$, or 1 . This accounts immediately for the irrelevance of syntax as well as the surprising relevance of phonology to hyperbaton. In this section we lay out more generally what phonological movement looks like, following Agbayani \& Golston (2010a, 2015), which is similar in most respects to the approach of Bennett, Elfner \& McCloskey (to appear).

The idea is that phonology is roughly like syntax, with structure, recursion, and movement. Following most work in generative grammar, we assume that syntax moves words and phrases $\left(\mathrm{X}^{0}, \mathrm{XP}\right)$ to head and specifier positions, is syntax-sensitive, and phonology-free (Zwicky \& Pullum 1986ab). In parallel fashion, phonology moves words and phrases $(\omega, \varphi)$ to the edges of $\omega, \varphi$ and $\mathrm{l}$, is syntax-free, and phonology-sensitive. Syntax feeds phonology and is not co-present with it (contra Zec \& Inkelas 1990), so that all syntactic representations and features are lost in the translation to prosodic structure. We assume a familiar Selkirkian prosodic interface and prosody, with three levels $\omega, \varphi$, and 1 , corresponding roughly to lexical heads, lexical phrases, and clauses (Itô \& Mester 2012, 2013).

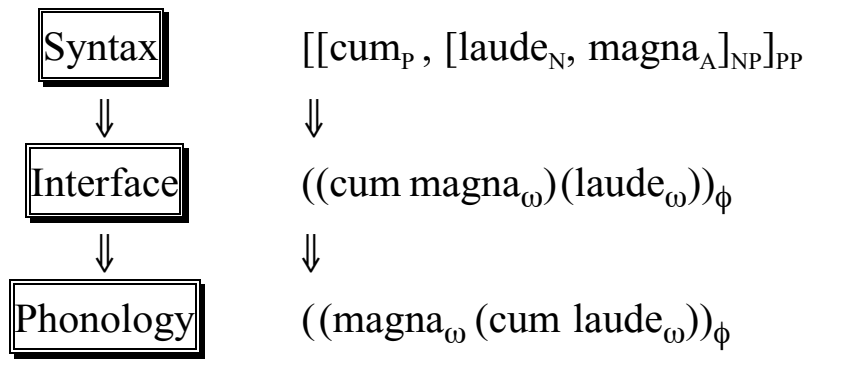

(immediate dominance, movement)

$\Downarrow$

(linear precedence, prosodic tree)

$\Downarrow$

(movement, postlexical phonology)

The prosodic tree results from what Büring (2013) calls narrow syntactic mapping (NSM), the edge- (Selkirk 1986), containment- (Truckenbrodt 1995), or match-based alignment (Selkirk 2009) that converts syntactic trees into the prosodic hierarchy. Büring identifies a second mapping as well: 
The second I will call extraneous feature mapping, EFM, by which I mean the way things like focus, topic, givenness etc. are reflected in prosody. Unlike NSM, EFM relates to features and properties that probably wouldn't have a life in syntax, were it not for their prosodic effects. (2013: 862)

We take the initial interface between syntax and phonology to be the prosodic structure with nothing moved that wasn't moved syntactically. In languages without phonological movement, the following constraints are high-ranked and keep everything in situ (cf. Agbayani \& Golston 2010a: 158):

(86) StAYFt No phonological foot moves.

STAY $\omega$ No prosodic word moves.

STAY $\varphi$ No phonological phrase moves.

These StAY constraints play the role that NoShifT plays in Bennett, Elfner \& McCloskey (to appear). We hypothesize that STAYFT is undominated in Latin, so nothing smaller than $\omega$ and $\varphi$ moves; we treat conjunctions, complementizers, and (monosyllabic) prepositions as mere feet in Latin, which keeps them from fronting and from occurring phrase-finally; to simplify the following presentation we will not consider cases that front a foot, as this never occurs in the language.

We attribute hyperbaton to a constraint (Agbayani \& Golston 2010a:158) that fronts material that is focused, foregrounded, topicalized and the like:

(87) PromLeft Prominent material occurs to the left of its interface position.

PromLeft forces discourse prominent material to front; we posit no dedicated topic or focus positons in the phonology, merely a tree with the usual $\omega s, \varphi s$ and $1 .^{15}$ Anything that shows up somewhere to the left of where the syntax put it is focused or topicalized to some degree. A similar variability of positioning is found with pronoun postposing in Irish, where the relevant pronouns can remain in situ (if the vowel is lengthened), or move to the right edges of following $\varphi s$ (Bennett, Elfner \& McCloskey to appear). PromLefT may well have been triggered in Latin by the alignment of some kind of focal pitch accent (cf. Szendrói 2001 on Hungarian), but the orthography and known phonetics of Latin do not indicate either way whether such an accent was present.

${ }^{15}$ Constraints that directly align focus with the left (or right) edges of $\omega, \varphi$ and 1 could work likewise; see Féry 2013. 
We do know, however, that Latin allowed prominence to be marked in situ (83a), and that it allowed prominent material to be fronted a fairly short distance (83bc), or to the very front of a clause (83de). We model the optionality of movement with a partially ordered grammar, following Reynolds 1994 and Anttila 1997. The relative ranking of PROMLEFT, STAY $\omega$ and STAY $\varphi$ is not fixed on this account, so that the grammar sometimes has PROMLEFT outranking STAY $\omega$ and STAY $\varphi$, yielding hyperbaton, and sometimes has STAY $\omega$ and STAY $\varphi$ outranking PROMLEFT, yielding prominence in situ. We model the in situ type below, where moving communem (b) or fructum (c) fatally violates STAY $\omega$. We have italicized communen below to show that it bears a general feature $\mathrm{F}$ common to focus and topicalization:

In situ prominence when STAY $\varphi$ and STAY $\omega>$ PROMLEFT

\begin{tabular}{|c|c|c|c|}
\hline$\left.\left.(\text { ad communem })_{\omega}\right)_{\omega}(\text { fructum })_{\omega}\right)_{\varphi}$ & STAY $\varphi$ & STAY $\omega$ & PROMLEFT \\
\hline a. $\left.(\text { ad communem })_{\omega}(\text { fructum })_{\omega}\right)_{\varphi}$ & & & * \\
\hline b. $\quad\left(\left(\right.\right.$ communem $_{\omega}\left(\text { ad fructum }{ }_{\omega}\right)_{\varphi}$ & & $* !$ & \\
\hline c. $\left((\text { fructum })_{\omega}\left(\text { ad } \text { communem }_{\omega}\right)\right)_{\varphi}$ & & $* !$ & $*$ \\
\hline
\end{tabular}

The faithful candidate (a) wins because of momentarily high-ranked STAY $\omega$, which kills candidates (b) and (c), each of which fronts something. When these STAY constraints are dominated by PROMLEFT we get movement of the focused adjective, in magna cum laude fashion:

\begin{tabular}{|c|c|c|c|}
\hline$\left.\left(\text { ad } \text { communem }_{\omega}\right)_{\omega}(\text { fructum })_{\omega}\right)_{\varphi}$ & PROMLEFT & $\operatorname{STAY} \varphi$ & STAY $\omega$ \\
\hline a. $\left.\left(\operatorname{ad} \text { communem }_{\omega}\right)_{\omega}(\text { fructum })_{\omega}\right)_{\varphi}$ & $* !$ & & \\
\hline b. $\quad\left((\text { communem })_{\omega}(\text { ad fructum })_{\omega}\right)_{\varphi}$ & & & $*$ \\
\hline c. $\left.\quad\left((\text { fructum })_{\omega}(\text { ad communem })_{\omega}\right)\right)_{\varphi}$ & $* !$ & & $*$ \\
\hline
\end{tabular}

Candidate (a) again has nothing fronted, but the violation of PROMLEFT is now fatal. Similarly for (c), which leaves F-marked communem in situ, leaving (b) as the winner.

Far less commonly, Latin fronts the noun and strands the adjective (D\&S 2006:572):

parte in alia [__ $]$

side $_{\mathrm{ABL}}$ on other $_{\mathrm{ABL}}$

'on the other side" (Livy 26.46.2; app. crit.) 
We attribute this to the noun being prominent rather than the adjective; from there the analysis is the same as it was for the magna cum laude type of case:

\begin{tabular}{|c|c|c|c|}
\hline$\left.\left(\text { in } \operatorname{alia}_{\omega}\right)_{\omega}(\text { parte })_{\omega}\right)_{\varphi}$ & PromLEFT & $\operatorname{STAY} \varphi$ & STAY $\omega$ \\
\hline a. $\left.\quad\left(\text { in } \operatorname{alia}_{\omega}\right)_{\omega}(\text { parte })_{\omega}\right)_{\varphi}$ & $* !$ & & \\
\hline b. $\quad\left((\text { alia })_{\omega}\left(\text { in } \text { parte }_{\omega}\right)_{\varphi}\right.$ & $* !$ & & $*$ \\
\hline c. $\left((\text { parte })_{\omega}(\text { in alia } \omega)\right)_{\varphi}$ & & & $*$ \\
\hline
\end{tabular}

Why adjective fronting should be more common than hyperbaton of nouns is beyond the scope of this paper; we assume it is due to pragmatic considerations and just note here that when fronting of nouns does occur, everything proceeds as expected.

Recall that Latin forbids stranding a monosyllabic preposition in hyperbaton: *magna laude cum (3.15). We propose that such prepositions cannot occur phrase-finally because they are prosodically just feet and because Latin requires that phonological phrases end in nothing less than a $\omega$. Selkirk (1996:199ff) notes the same prohibition for English, based on the inadmissibility of reduced prepositions in sentences like ${ }^{*}$ Who did you do it [for]? and reduced auxiliaries like *This is what the problem's. She proposes the following:

(92) $\operatorname{AlignR}(\phi, \omega)$ : Every phonological phrase ends in a prosodic word.

English avoids violation of $\operatorname{ALIGNR}(\varphi, \omega)$ by promoting final function words to $\omega$; we propose here that Latin avoids violation of $\operatorname{ALIGNR}(\varphi, \omega)$ by blocking hyperbaton that would put prosodically light function words in phrase-final position. This links the lack of full hyperbaton in PPs to the lack of fronting a preposition: if prepositions are just feet they will be both too small to move and too small to strand phrase-finally. This also allows us a principled solution to why mecum, tecum, and other pronoun + cum forms are allowed. They don't contain any lexical XP that would constitute a $\varphi$ and thus slide under the radar of the alignment constraint in (92). PPs with relative pronouns are allowed for the same reason: quibus de 'about which', quos ad 'towards which', etc., don't contain lexical material that constitutes a $\varphi$ and so are phrased as prosodic words that are not regulated by $\operatorname{ALIgNR}(\varphi, \omega)$.

Latin allows fronting that is less local than these cases, as we have seen. In (4) we saw a case where part of a PP fronts past a verb: ad communem afferre fructum 'to contribute to the common good'. This is the result of the F-feature spreading to the maximal $\omega$ that contains it, so that ad communem 'to common' is assigned $\mathrm{F}$ rather than just communem. From there the phonology precedes as before to front whatever is F-marked: 


\begin{tabular}{|c|c|c|c|}
\hline$\left.\left((\text { afferre })_{\omega}(\text { ad communem })_{\omega}\right)_{\omega}(\text { fructum })_{\omega}\right)_{\varphi}$ & PROMLEFT & STAY $\varphi$ & STAY $\omega$ \\
\hline a. $\quad\left((\text { afferre })_{\omega}(\text { ad communem })_{\omega}(\text { fructum })_{\omega}\right)_{\varphi}$ & $* !$ & & \\
\hline b. $\quad\left((\text { communem })_{\omega}(\text { afferre })_{\omega}(\text { ad fructum })_{\omega}\right)_{\varphi}$ & $* !$ & & * \\
\hline c. $\left(\left(\text { ad } \text { communem }_{\omega}\right)_{\omega}(\text { afferre })_{\omega}(\text { fructum })_{\omega}\right)_{\varphi}$ & & & $*$ \\
\hline d. $\left.\left.\quad\left((\text { ad communem })_{\omega}\right)_{\omega}(\text { fructum })_{\omega}\right)_{\varphi}(\text { afferre })_{\omega}\right)_{\varphi}$ & & & $* * !$ \\
\hline
\end{tabular}

Two candidates fatally fail to front focused material: (a) strands ad communem and (b) strands $a d$. The decision between the remaining (c) and (d) falls to STAY $\omega$, which is violated minimally by (c) and superfluously by (d), since fructum is moved but not F-marked. When the partially ordered grammar ranks the STAY $\varphi$ and STAY $\omega$ above PROMLEFT, the faithful candidate (a) wins and we get prominence in situ. When the entire PP is F-marked, PrOMLEFT fronts the whole thing.

It might seem that fronting past the verb in (93) is forced by the fact that ad communem is F-marked rather than just communem. If ad communem is to be fronted, after all, it has to occur to the left of something, which is minimally afferre. But there is data to show that Latin allows non-local fronting even when local fronting would suffice. Consider fronted magno:

$\begin{array}{lll}\text { magno } & \text { equidem }[\text { cum } & \text { dolore }] \\ \text { great } & \text { though with } & \text { sorrow }\end{array}$

'though with great sorrow' (Cicero, Att. 10.4.5)

magno could also have been fronted minimally, just to the left of cum, resulting in a magna cum laude structure after equidem 'though'. This is reminiscent of phonological movement in Irish, which shifts a light pronoun rightward so it doesn't occur initially in its phonological phrase. Crucially, Irish can shift the pronoun to the end of the first phrase to its right, or the next, or the next:

(95) Pronoun postposing in Irish (Bennett, Elfner \& McCloskey to appear)

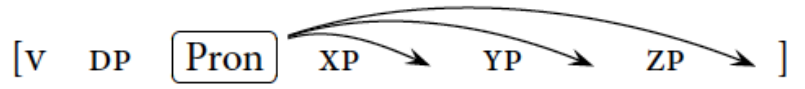

In much the same way, material can be fronted in Latin just a short distance or further to the left, as we saw in (83).

The avoidance of cum cum (3.15) is credited to the constraint *ECHO (Yip 1998), at the 
level of the recursive prosodic word in Latin:

(96) *ECHO No phonologically identical $\omega$ s occur within a $\omega$.

The $\omega$-within-a- $\omega$ formulation makes * ECHO applicable only to homophonous function words, which are recursively embedded into prosodic words formed around lexical items, nouns, verbs, and adjectives. Thus *ECHO doesn't preclude Call a spade a spade or the like, since each occurrence of a spade is its own prosodic word: $\left((\mathrm{kol})_{\omega}\left(\partial \operatorname{speId}_{\omega}\right)_{\omega}\left(\partial \operatorname{speId}_{\omega}\right)_{\omega}\right)_{\varphi}$. Nor does it preclude the many compound function words like quisquis 'whoever' or quemquem 'whomever', even if they are recursive $\omega \mathrm{s}$, e.g., $\left(\left(\mathrm{k}^{\mathrm{w}} \mathrm{is}\right)_{\omega}\left(\mathrm{k}^{\mathrm{w}} \mathrm{is}\right)_{\omega}\right)_{\omega}$. Such words are created by compounding in the lexicon, which has its own constraint-ranking, not by hyperbaton in the postsyntactic phonology.

Our analysis of phonological movement is simple, because the prosodic trees within which the movement takes places are simple. An embedded $\omega$ can move to the left of the closest $\omega(97)$, or further past the next-closest $\omega(98)$ :

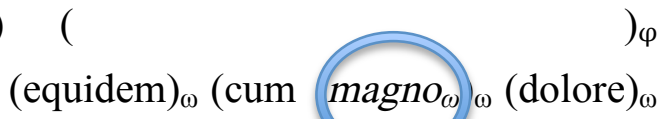

(98)

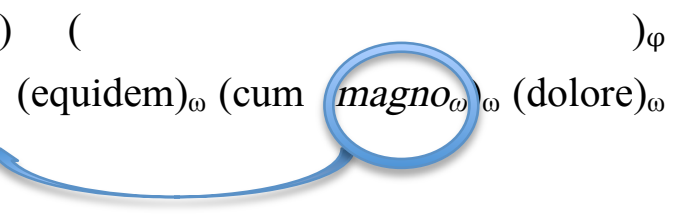

As in Irish, the distance moved seems to be optional, though further study should be done to confirm this. Following Selkirk (1995), we assume that F-marking on a complement like magno licenses F-marking on the head that selects it (cum), so that the head and its complement can can be marked if the complement is. This is what lies behind fronting not just part of the PP, but the whole thing:

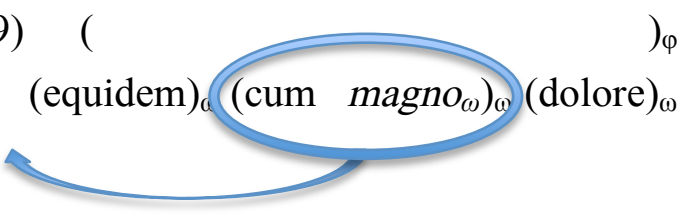

In her account of similar phenomena in Ukrainian, Teliga (2011) points out that such movement is not structure-preserving: it does not move a prosodic word to an empty prosodic word-position. Rather, the prosodic word is simply shunted leftwards, where it sits at the same 
level of structure it occupied before it moved. Phonological movement is meant to occur in a bracketed grid or its arboreal equivalent, not in a syntactic tree: we assume that the syntaxphonology interface transforms syntactic structure into prosodic structure once and for all (Selkirk 1986, et seq.), and that once prosodic structure is present, syntactic structure is unavailable and never directly referred to by any phonological process.

In this way our notion of phonological movement differs drastically from the ill-named 'movement-at-PF', in which syntactic constituents move in a syntactic tree (sometimes for phonological reasons), but late in the derivation and without LF consequences. The notion that syntactic structure persists into 'Phonetic Form' is incoherent in our view. We reject the notion of 'PF' entirely, and posit no components in the grammar other than a phonology-blind syntax and a syntax-blind phonology. Under the present proposal, morphology and syntax play no role in phonological movement, unlike PF movement analyses such as Kidwai 1999 (for XP scrambling) and Embick \& Noyer 2001 (for morpho-syntactic processes). Phonological movement as we understand it takes place entirely in the phonological component and has no effect whatsoever on syntax.

The complete irrelevance of syntax to hyperbaton follows from our analysis immediately: hyperbaton is blind to syntactic categories (3.1), syntactic levels (3.2), syntactic constituency (3.3), syntactic islands (3.4), locality (3.5), binding (3.8), superiority (3.11), and proper names (3.12) because it takes place in the phonology, where such things are undefined. Hyperbaton past a complementizer (3.6) is just movement to the left edge of $t$. Thus the clause-boundedness of hyperbaton can be captured without reference to syntax: it follows from the fact that a clause is wrapped inside of an 1 and that hyperbaton is bounded by the top node of the prosodic hierarchy, 1 .

We've seen that prosodic recursion plays a crucial part in this as well. The bizarre fronting past a sentential coordinator in meter (3.7) might be better understood with the help of prosodic recursion as well. A sentential coordinator like and or but is incorporated into the following clause rather than the preceding clause in Latin, just as coordinators conjoining XPs go with the rightmost XP prosodically. Presumably this gives us something like ${ }_{1} \&\left(_{1}\right.$ CLAUSE)), with recursion of 1 . In prose, hyperbaton can front material to the left of the inner 1 but no further (unless the $\&$ is a clitic, in which case the fronting must pass it). In meter, hyperbaton can front to the outer 1 , presumably because the meter wants as few prosodic breaks as possible within the line. This squeezing of prosody in meter might be what allows for fronting past (non-clitic) sentential conjunctions.

The fact that hyperbaton allows both partial and full movement of focused and topicalized constituents (3.9) is unremarkable from a phonological perspective. We saw above that hyperbaton can select the minimal prosodic word magno $\boldsymbol{\omega}_{\omega}$ in the PP $\left((\text { cum magno } \omega)_{\omega}\right.$ 
dolore $\left._{\omega}\right)_{\varphi}$ 'with great sorrow' and move it minimally to yield $\left((\text { magno })_{\omega}\left(\text { cum } \text { dolore }_{\omega}\right)_{\varphi}(97)\right.$ or further to yield something like (98). But hyperbaton can also select the next largest $\omega$ as it does in (99) and phonologically pied-pipe the preposition with the adjective. Or it can select the entire $\varphi$ and front the PP in its entirety as we saw in (49c) or the many cases of PP fronting in (3.15), where it is blocked by the OCP. This is presumably related to the fact that F-marking can project from the head of a phrase to the phrase itself, and from an internal argument of a phrase to the head that selects it (e.g., Selkirk 1995:553ff.).

The optionality of hyperbaton (3.10) is also easily modeled in the phonology, as we saw above ( $88 \mathrm{ff}$.). We have no numerical data for how common fronting is, so we cannot currently decide among the various formal approaches to variation in the literature (see Anttila 2012). The relevant point at present is that this kind of variation is common in phonology and amenable to analysis but rare and dubious in syntax.

The surprising relevance of phonology to hyperbaton also follows from our analysis: hyperbaton moves $\omega$ and $\varphi(3.12)$ because those are the constituents available to it in phonology; phonological movement is required by 'second position' particles because those particles have suffix-like requirements which block them from occurring phrase-initially (3.13); it is sensitive to the OCP (3.14) because that is a phonological issue and hyperbaton is a phonological process.

\section{Conclusion}

We have argued that hyperbaton in Latin is a case of phonological movement, a species of movement that is strictly prosodic in that it moves prosodic constituents to the edges of other prosodic constituents. Because it applies entirely in the phonological component of the grammar, it is sensitive to prosodic constituency, *ECHO, prosodic alignment, and the like, but insensitive to syntactic constituency, island conditions, syntactic category, and bar-level. Though it is sensitive to discourse prominence, it ignores LF issues like binding and scope. Hyperbaton is thus movement that is entirely syntax-free. This strongly suggests that syntax and phonology operate in different spheres, such that syntactic alternations have no phonological conditions, and phonological alternations have no syntactic conditions. As such, phenomena that require reference across the syntax-phonology divide cannot exist: any apparently syntactic movement that refers to phonology must be phonological movement, and any phonological alternation that apparently refers to a syntactic constituent must in fact refer to its phonological double, e.g., the phonological phrase.

The possibility of phonological movement opens up an intriguing parallelism between phonology and syntax that has, until recently, been largely unexplored. The diagnostics for phonological movement presented in this paper may be employed to uncover other cases of 
post-syntactic phonological movement crosslinguistically.

\section{References}

Abels, Klaus (2003). Successive cyclicity, anti-locality, and adposition stranding. Doctoral dissertation, University of Connecticut.

Ackema, Peter (2001). Colliding complementizers in Dutch: another syntactic OCP effect. LI 32. 717-727.

Adams, J. N. (1971). A type of hyperbaton in Latin prose. Proceedings of the Cambridge Philological Society 17. 1-16.

Adams, J. N. (1995). The language of the Vindolanda writing tablets: an interim report. The Journal of Roman Studies 85.86-134

Adams, J. N. (1996). Interpuncts as evidence for the enclitic character of personal pronouns in Latin. Zeitschrift für Papyrologie und Epigraphik, Band 111. 208-210.

Agbayani, Brian, and Chris Golston (2010a). Phonological movement in Classical Greek. Language 86.1. 133-167.

Agbayani, Brian, and Chris Golston (2010b). Second-position is first-position: Wackernagel's Law and the role of clausal conjunction. Indogermanische Forschungen 115. 1-21.

Agbayani, Brian, Chris Golston, and Dasha Henderer (2011). Phonological movement. In Mary Byram Washburn, Katherine McKinney-Bock, Erika Varis, Ann Sawyer, and Barbara Tomaszewicz (eds.), Proceedings of the 28th West Coast Conference on Formal Linguistics. 231-239.

Agbayani, Brian, Chris Golston, and Toru Ishii (2015). Syntactic and prosodic scrambling in Japanese. NLLT 33. 47-77.

Allen, W. S. (1973). Accent and Rhythm: prosodic features of Latin and Greek: a study in theory and reconstruction. Cambridge: Cambridge University Press.

Anttila, Arto (1997). Deriving variation from grammar. In Frans Hinskens, Roeland van Hout and Leo Wetzels (eds.), Variation, Change and Phonological Theory. Amsterdam: John Benjamins. 35-68.

Anttila, Arto (2012). Modeling phonological variation. In Abigail C. Cohn, Cécile Fougeron, and Marie Huffman (eds), The Oxford Handbook of Laboratory Phonology. Oxford: Oxford University Press. 76-91.

Bašić, Monica. (2004). Nominal subextractions and the structure of NPS in Serbian and English. MPhil, University of Tromsø.

Bauer, Brigitte L. M. (1995). The emergence and development of SVO patterning in Latin and French. Oxford: Oxford University Press. 
Belletti, Adrianna (2001). "Inversion" as focalization. In Aafke Hulk and Jean-Yves Pollock (eds.), Subject inversion in Romance and the Theory of Universal Grammar. Oxford: Oxford University Press. 60-90.

Belletti, Adrianna (2004). Aspects of the low IP area. In The structure of IP and CP. The cartography of syntactic structures, vol. 2, Luigi Rizzi (ed.), 16-51. Oxford: Oxford University Press.

Bennett, Ryan, Emily Elfner, and Jim McCloskey (to appear). Lightest to the right: an apparently anomalous displacement in Irish. Linguistic Inquiry.

Blair, Walter. (1874). Latin pronunciation: an inquiry into the proper sound of the Latin language during the classical period. New York and Chicago: A. S. Barnes \& Co.

Bolkestein, A. Machtelt (2001). Random scrambling? Constraints on discontinuity in Latin noun phrases. In Claude Maussy (ed.), De lingua Latina novae quaestiones: Actes du Xe colloque international de linguistique latine, Paris-Sevres, 19-23 avril 1999. 245-258. Leuven: Peeters.

Booij, Geert Booij (1996). Cliticization as prosodic integration. The Linguistic Review 13. 219-242.

Bošković, Željko (2005). On the locality of left branch extraction and the structure of NP. Studia Linguistica 59.1-45.

Bošković, Željko (2009). On Leo Tolstoy, its structure, case, left-branch extraction, and prosodic inversion. In Steven Franks, Brian D. Joseph, and Vrinda Chidambaram (eds.), A linguist's linguist: studies in South Slavic linguistics in honor of E. Wayles Browne. 99-122.

Bošković, Željko and Daiko Takahashi. (1998). Scrambling and last resort. Linguistic Inquiry 29. 347-366.

Büring, Daniel (2013). Syntax, information structure and prosody. In Marcel den Dikken (ed.), The Cambridge Handbook of Generative Syntax. Cambridge: Cambridge University Press. 860-896.

Butler, Harold Edgeworth, ed. (1922). The Institutio Oratoria of Quintilian. Harvard University Press.

Carnie, Andrew (2010). Constituent structure. Oxford University Press.

Carey, John (1808). Latin prosody made easy. London: Longman, Hurst, Rees, and Orme. Ćavar, Damir and Gisbert Fanselow. (2000). Discontinuous constituents in Slavic and Germanic languages. Ms. University of Hamburg and University of Potsdam.

Chomsky, Noam (1973). Conditions on transformations. In Stephen R. Anderson and Paul Kiparsky, eds., A festschrift for Morris Halle, 232-286. New York:Holt, Rinehart and Winston.

Chomsky, Noam (1986). Barriers. Cambridge, Mass: MIT Press. 
Corssen, Wilhelm Paul (1859). Über Aussprache, Vokalismus und Betonung der lateinischen Sprache, Zweiter Band. Leipzig: Teubner.

Danckaert, Lieven (2012). Latin embedded clauses: the left periphery. Amsterdam: John Benjamins.

Devine, A.M. and Laurence D. Stephens (2000). Discontinuous syntax: hyperbaton in Greek. New York: Oxford University Press.

Devine, A.M. and Laurence D. Stephens (2006). Latin word order: structured meaning and information. New York: Oxford University Press.

Dover, K. J. 1960. Greek word order. Cambridge: Cambridge University Press.

Embick, David, and Rolf Noyer (2001). Movement operations after syntax. LI 32.4. 555-595.

Fanselow, Gisbert, and Denisa Lenertová (2010). Left peripheral focus: mismatches between syntax and information structure. NLLT 29:169-209.

Féry, Caroline. (2013). Focus as prosodic alignment. NLLT 31:683-734.

Fortson IV, Benjamin W. (2008). Language and rhythm in Plautus. Synchronic and diachronic studies. Berlin, New York: Walter de Gruyter.

Fortson IV, Benjamin W. (2010). Reconstructing the history of Latin and Sabellic adpositional morphosyntax. American Journal of Philology, 131.1, 121-154.

Franks, Steven and Ljiljane Progovac. (1994). On the placement of Serbo-Croatian clitics. Indiana Linguistic Studies 7.69-78.

Golston, Chris (1991). Minimal word, minimal affix. NELS 21, ed. by Tim Sherer. 95-110.

Golston, Chris (1995). Syntax outranks phonology: evidence from Ancient Greek. Phonology 12. 343-368.

Greenough. J. B. (1894). Early latin prosody. Harvard Studies in Classical Philology, Vol. 5, 57-71.

Grohmann, Kleanthes. (2002). Anti-locality and clause types. Theoretical Linguistics 28.43-72.

Halpern, Aaron (1995). On the placement and morphology of clitics. Dissertations in Linguistics, CSLI. Stanford University.

Hayes, Bruce (1989). The prosodic hierarchy in meter. In: Paul Kiparsky and Gilbert Youmans (eds.), Rhythm and Meter. San Diego: Academic Press. 201-260.

Henderer, Dasha (2010). Prosodic movement in colloquial Russian. MS, California State University Fresno.

http://zimmer.csufresno.edu/ chrisg/Student_Work_files/Dasha\%20HENDERER.pdf

Huang, C.-T. James (1982). Logical relations in Chinese and the theory of grammar. Doctoral dissertation, MIT.

Itô, Junko and Armin Mester. (2012). Recursive prosodic phrasing in Japanese. In, Toni Borowsky, Shigeto Kawahara, Mariko Sugahara, and Takahito Shinya (eds.). Prosody 
Matters. Essays in Honor of Elisabeth Selkirk. Advances in Optimality Theory Series.

Elsevier. 280-303.

Itô, Junko \& Armin Mester. (2013). Prosodic subcategories in Japanese. Lingua 124. 20-40. Inkelas, Sharon. (1989). Prosodic constituency in the lexicon. Doctoral dissertation, Stanford University.

Kayne, Richard S. (1994). The antisymmetry of syntax. Cambridge, Mass: MIT Press. Kayne, Richard S. (2005). Some notes on comparative syntax, with special reference to English and French. In Guglielmo Cinque and Richard S. Kayne (eds.), The Oxford handbook of comparative syntax. Oxford: Oxford University Press. 3-69.

Kidwai, Ayesha (1999). Word order and focus positions in Universal Grammar. In Georges Rebuschi and Laurice Tuller (eds.), The grammar of focus. Amsterdam: John Benjamins. 213-244.

Ladd, D. R. (1986). Intonational phrasing: the case for recursive prosodic structure. Phonology 3. 311-340.

Laughton, E. (1960). "Observations on the style of Varro". The Classical Quarterly, New Series 10.1:1-28.

Leben, Will (1973). Suprasegmental phonology. Doctoral dissertation, MIT.

Mercado, Angelo (2012). Italic Verse: A Study of the Poetic Remains of Old Latin, Faliscan, and Sabellic. Innsbrucker Beiträge zur Sprachwissenschaft, Bd 145. Innsbruck: Institut für Sprachen und Literaturen der Universität Innsbruck Bereich Sprachwissenschaft. Mester, Armin (1994). The quantitative trochee in Latin. NLLT, 12.1-61. Munn, Alan (1993). Topics in the Syntax and Semantics of Coordinate Structures. Doctoral dissertation, University of Maryland.

Nespor, Marina, and Irene Vogel (1986). Prosodic Phonology. Dordrecht: Foris.

Nevins, Andrew (2012). Haplological dissimilation at distinct stages of exponence. In Jochen Trommer (ed.), The Morphology and Phonology of Exponence. Oxford Oxford University Press. 84-116.

Nunes, Jairo (2004). Linearization of chains and sideward movement. Cambridge, Mass: MIT Press.

Panhuis, Dirk G. J. (1982). The communicative perspective in the sentence: a study of Latin word order. Amsterdam: John Benjamins.

Parsons, Jed (1999). A new approach to the Saturnian verse and its relation to Latin prosody. Transactions of the American Philological Association 129. 117-137.

Pinkster, Harm (1990). Latin syntax and semantics. London and New York: Routledge.

Pinkster, Harm (2005). Changing patterns of discontinuity in Latin. Paper presented at the 13th International Colloquium on Latin Linguistics, Brussels. 
Powell, Jonathan G. F. (2010). Hyperbaton and register in Cicero. In Eleanor Dickey and Anna Chahoud (eds.), Colloquial and Literary Latin. Cambridge: Cambridge University Press.163-185.

Radford, Robert S. (1903). The Latin monosyllables in their relation to accent and quantity. A study in the verse of Terence. Transactions and Proceedings of the American Philological Association, 34.60-103.

Radford, Robert S. (1904). On the recession of the Latin accent in connection with monosyllabic words and the traditional word-order. Parts 1 and II. The American Journal of Philology 25.2, 147-162 and 25.4, 256-273.

Radford, Andrew (1977). Counter-filtering rules. York Papers in Linguistics 7:7-45.

Reynolds, William T. 1994. Variation and Phonological Theory. Ph.D. dissertation, Department of Linguistics, University of Pennsylvania.

Ribbeck, Otto (ed.). (1866). P. Vergili Maronis: Opera, Vol. 5. Leipzig: Teubner. Rizzi, Luigi (1997). The fine structure of the left periphery. In Liliane Haegeman (ed.), Elements of Grammar: Handbook of Generative Syntax. Dordrecht: Kluwer. 281-337.

Ross, John R. (1967). Constraints on variables in syntax. PhD Dissertation, MIT.

Saito, Mamoru (1989). Scrambling as semantically vacuous A'-movement. In Mark Baltin and Anthony Kroch (eds.), Alternative conceptions of phrase structure. Chicago: University of Chicago Press. 182-200.

Selkirk, Elizabeth O. (1984). Phonology and Syntax. Cambridge: MIT Press.

Selkirk, Elizabeth O. (1986). On derived domains in sentence phonology. Phonology Yearbook 3. 371-405.

Selkirk, Elizabeth O. (1995). Sentence prosody: intonation, stress, and phrasing. In John Goldsmith (ed.), The handbook of phonological theory. 550-569.

Selkirk, Elizabeth O. (1996). The prosodic structure of function words. In James L. Morgan and Katherine Demuth (eds.), From signal to syntax: bootstrapping from speech to grammar in early acquisition. 187-214. Mahwah, New Jersey: Lawrence Erlbaum Associates.

Selkirk, Elizabeth O. (2005). Comments on intonational phrasing in English. In Sonia Frota, Marina Vigario, Maria Joao Freitas (eds.), Prosodies. Berlin: Mouton de Gruyter. 11-58.

Selkirk, Elisabeth O. (2009). On clause and intonational phrase in Japanese: the syntactic grounding of prosodic constituent strcture. Gengo Kyenku 136. 35-73.

Selkirk, Elisabeth O. (2011). The syntax-phonology interface. In John A. Goldsmith, Jason Riggle \& Alan C. L. Yu (eds.) The Handbook of Phonological Theory, 2nd edition. 435-484. Smyth, Herbert Weir (1920). Greek grammar for colleges. New York: American Book Company.

Speas, Margaret (1990). Phrase structure in natural language. Dordrecht: Kluwer. 
Spevak, Olga (2010). Constituent order in Classical Latin prose. Amsterdam: John Benjamins.

Szendrôi, Kriszta (2001). Focus and the syntax-phonology interface. Ph.D dissertation, University College London.

Takahashi, Daiko (1993). Minimality of movement. Doctoral dissertation, University of Connecticut.

Teliga, Viktoriia (2011). Phonological movement in Ukrainian. Master's thesis, California State University Fresno.

Truckenbrodt, Hubert (1995). Phonological phrases: their relation to syntax, focus and prominence. Doctoral dissertation, MIT.

Truckenbrodt, Hubert (1999). On the relation between syntactic phrases and phonological phrases. LI 30. 219-255.

Probert, Philomen (2002). On the prosody of Latin enclitics. In Hartmann, Ina J. and Andreas Willi (eds.), Oxford University Working Papers in Linguistics, Philology \& Phonetics, 7.181-206.

Wackernagel, Jacob (1892). Über ein Gesetz der indo-germanischen Wortstellung. Indogermanische Forschungen 1, 333-436.

Wexler, Kenneth and Peter Culicover (1980). Formal Principles of Language Acquisition. Cambridge, Mass: MIT Press.

Wingo, E. O. (1972). Latin punctuation in the Classical Age. The Hague.

Yip, Moira (1998). Identity avoidance in phonology and morphology. In S. G. Lapointe, D. K. Brentari, and P. M. Farrell (eds.), Morphology and its relation to phonology and syntax. Stanford, CA: CSLI. 216-247.

Zec, Draga, and Sharon Inkelas (1990). Prosodically constrained syntax. In Sharon Inkelas and Draga Zec (eds.), The phonology-syntax connection. Stanford: CSLI publications / Chicago: University of Chicago Press. 365-378.

Zetzel, J.E.G. (1974). Ennian experiments. The American Journal of Philology, 95.2, 137-140. Zwicky, Arnold and Geoffrey Pullum (1986a). The principle of phonology-free syntax:

Introductory remarks. Ohio State University Working Papers in Linguistics 32. 63-91.

Zwicky, Arnold and Geoffrey Pullum (1986b). Two spurious counterexamples to the principle of phonology-free syntax. The Ohio State University Working Papers in Linguistics 32. 92-99. 